\title{
The long-term effects of oppression: Prussia, Political Catholicism and the Alternative für Deutschland
}

\author{
Lukas Haffert, University of Zurich \\ haffert@ipz.uzh.ch
}

This version: August 2020

Keywords: Radical Right, Political Catholicism, Electoral Geography, Historical Persistence, Regional Context, Prussia

\begin{abstract}
$^{1}$
Contemporary political behavior is often affected by historical legacies, but the specific mechanisms through which these legacies are transmitted are difficult to pin down. This paper argues that historical political conflicts can affect political behavior over several generations when they trigger an enduring organizational mobilization. It studies how the oppression of German Catholics in the $19^{\text {th }}$ century led to a regionally differentiated mobilization of political Catholicism that still affects political support for the radical right Alternative für Deutschland (AfD) today. Using newly collected data on historical oppression events, it shows that Catholic regions where oppression was intense saw greater mobilization of Catholic lay organizations than Catholic regions where oppression was milder and show lower support for the AfD today. The paper thus contributes to the literature on the historical determinants of political behavior as well as to the question which regional context effects strengthen or weaken the radical right.
\end{abstract}

\footnotetext{
${ }^{1}$ Earlier versions of this paper were presented at the Swiss Political Science Assocation annual meeting in Zurich in February 2019 and the Conference of Europeanists in Madrid in June 2019. I would like to thank Philip Manow and Hanna Schwander for generously sharing data, Antonius Liedhegener for invaluable pointers to sources on political Catholicism, and Nils Redeker, Valentin Lang, Silja Häusermann, Lukas Rudolph, Daniel Bischof, Kai Gehring, Josef Hien, and Delia Zollinger for helpful comments.
} 


\section{Introduction}

Why are people in some regions more willing to support the radical right while people in other regions are more reluctant to do so? A growing literature argues that such differences are partly driven by long historical continuities underlying political behavior (Cantoni, et al. 2019, Hoerner, et al. 2019, Ochsner and Roesel 2019, Homola, et al. 2020). Where other studies emphasize contemporary economic or cultural grievances (Inglehart and Norris 2016, Gidron and Hall 2017, Colantone and Stanig 2018), these contributions seek the explanations for variation in radical right support in the past.

An important challenge for such arguments about historical persistence, however, is pinning down the mechanism by which historical experiences are transmitted to later generations (Neundorf and Pop-Eleches 2019). How does a historical event still affect people who are separated from this event by more than a century? Transmitting attitudes over such a long time period usually requires some form of institutional stabilization. In this study, I emphasize the role of organizational mobilization as an important source of such stabilization. I argue that political conflicts can trigger the creation of persistent social and organizational structures which continue to shape people's behavior long after the original conflicts have been assuaged.

To examine this argument empirically, I study the relationship between the historical mobilization of Catholic lay organizations and the strength of the Alternative für Deutschland (AfD) in the German federal election of 2017. Catholicism has historically been a factor that has heavily influenced the structure of the German party system and has inhibited people from voting for authoritarian parties (Falter 1991, Spenkuch and Tillmann 2018). This uniform effect of Catholicism, however, masks important regional variation in the historical development of political Catholicism. In some party of Germany, particularly in Prussia, Catholics were oppressed by the state and developed a coherent and closed "milieu" - a dense network of Catholic clubs, associations, Catholic newspapers, and educational activities (Lepsius 1966) - in response to this oppression. In most other German states, by contrast, there was no comparable oppression and a similar milieu did not develop.

Against this background, I argue that the mobilization of the Catholic milieu provides the mechanism which links the regional history of oppression to contemporary AfD vote shares. Where Catholics were oppressed, they developed a tight-knit Catholic milieu whose remainders still affect political behavior today and reduce Catholics' propensity to vote for an authoritarian party. Where they were not oppressed, a comparable milieu did not develop, and Catholics remained much more open to vote for such a party.

A look at the regional distribution of Catholics and of AfD results in West Germany in the federal election of 2017 provides some provisional support for this argument (Figure 1). The AfD has its strongest results in highly Catholic regions (in south-eastern Bavaria). However, it also has its weakest results in regions where Catholicism is strong (along the Dutch border). One main difference between these regions is that the latter historically belonged to Prussia, whereas the former did not. 
In the rest of the paper, I present more systematic evidence for this association. I measure historical oppression using two different strategies. Firstly, I distinguish between places that historically belonged to Prussia and those that did not, since Catholics mainly experienced oppression in Prussia. Secondly, I have collected data on about 500 specific events of Catholic oppression during the Kulturkampf in the years 1875/1876. These events were chronicled by the Frankfurter Zeitung for the entire area of the German empire and show huge regional variation in the intensity of oppression.

Using these alternative measures, I employ three different strategies to analyze the links between historical oppression and contemporary voting. Firstly, using municipal-level election results across West Germany², I demonstrate that the AfD performs significantly worse in Catholic regions where Catholics were oppressed than in Catholic regions without oppression. Secondly, I analyze this relationship within the state of Rhineland-Palatinate, exploiting the discontinuity at the former Prussian-Bavarian border within this state. Thirdly, I also find evidence of a stronger rejection of the AfD among Catholics in historically oppressed regions in individual level survey data.

Finally, I provide evidence of the mechanism underlying this relationship. Using data on the intensity of Catholic civil society mobilization in the early 20th century, and on the Catholic lay milieu today, I show that the intensity of oppression predicts the strength of Catholic mobilization and that mobilization levels in turn predict electoral behavior: Catholics are more heavily opposed to the AfD in regions where Catholics were highly mobilized in the past and in the present.

This study thus contributes to the question how historical legacies are being transmitted. Moreover, its results also speak to the literature on the role of regional context effects for the electoral success of the radical right (McNamara 2017, Fitzgerald 2018, Harteveld, et al. 2018). In line with this literature, the study finds that the decision (not) to vote for the radical right is strongly influenced by regional context factors. However, it emphasizes that the role of this context is always historically specific. Living in a region that is majority Catholic can have very different effects on political behavior, depending on the region's historical trajectory.

In the following pages, I develop my argument in greater detail. I first explain how the historical oppression of Catholics led to specific forms of political mobilization and why this mobilization may still affect voting patterns today. In a second step, I explain the data and the empirical strategy. I then show that the association between historical oppression and Catholic AfD support holds at different levels of analysis, before I analyze the mechanism behind this association. The final section discusses the implications of my findings and argues that understanding the variation in radical right voting requires analyzing not only the factors that attract certain people to the radical right, but also those which inhibit others from voting for these parties.

\footnotetext{
${ }^{2}$ I restrict my analysis to former West Germany, since my argument about the transmission of historical experiences into the present relies on the continuity in the organizational and institutional context. In former East Germany, the combined effect of 56 years of fascist and socialist rule was to systematically dismantle this context.
} 


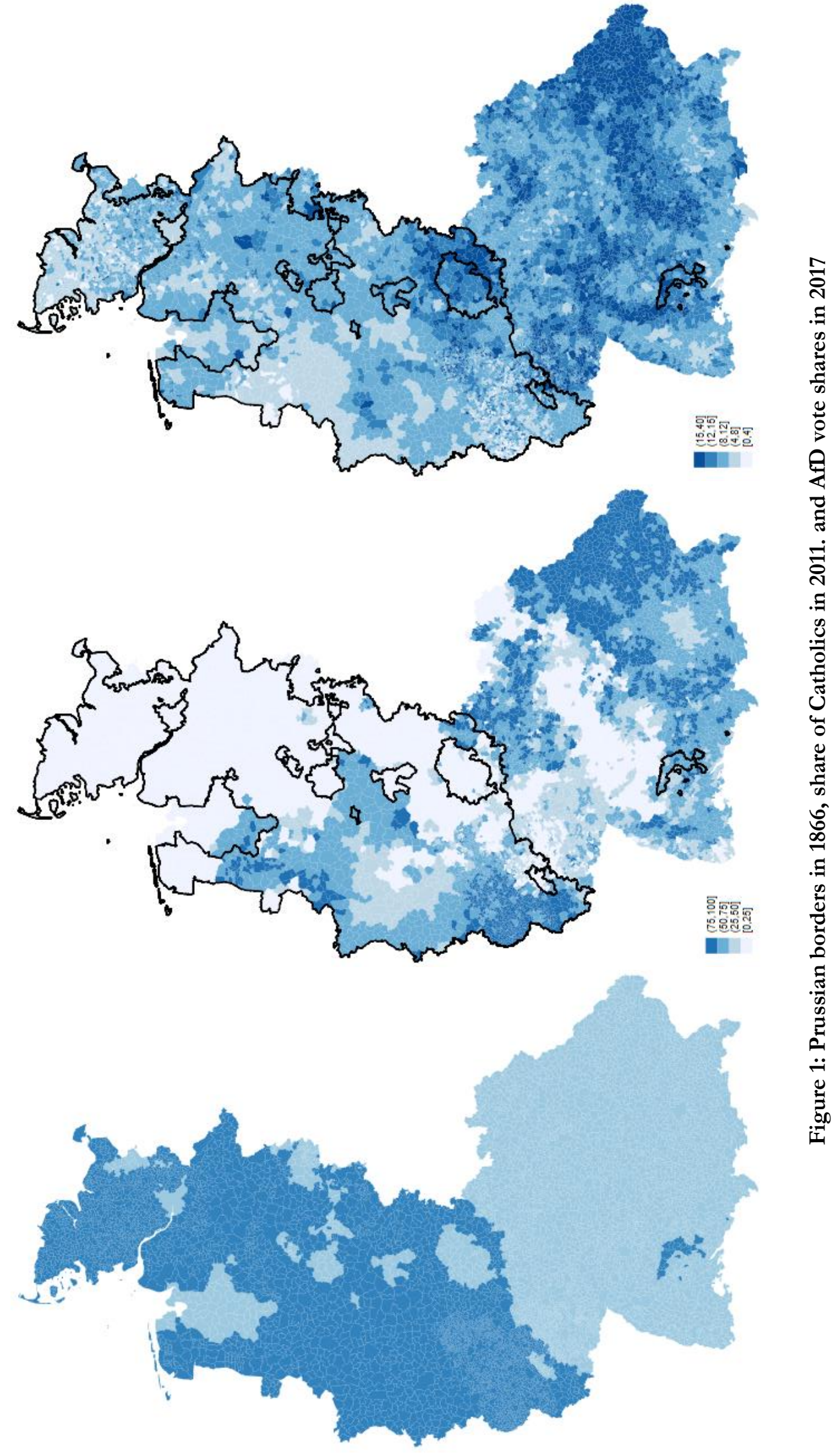




\section{Theory}

\section{Mechanisms of historical persistence}

The rapidly growing literature on attitudinal legacies argues that a regionally specific history of political conflict can still affect political behavior decades or even centuries after the original event (Putnam 1993, Charnysh 2015, Acharya, et al. 2016). While this literature studies a wide range of empirical phenomena, a number of recent contributions specifically address historical patterns underlying the success of right-wing authoritarian parties. Voigtländer and Voth 2012 show that plague-era pogroms in Germany predict Nazi vote shares in the 1920s. Ochsner and Roesel 2019 demonstrate that the Austrian FPÖ performs better in municipalities that were pillaged by Turkish troops in the $16^{\text {th }}$ and $17^{\text {th }}$ century. With regard to the AfD, Homola, et al. 2020 show that it is stronger in the vicinity of former concentration camps (see also Hoerner, et al. 2019). Moreover, Cantoni, Hagemeister and Westcott (2019) show that it performs systematically better in regions where the NSDAP had been particularly strong.

There is thus wide agreement that regional historical legacies can affect political outcomes today. Where this literature has made less progress so far, is in identifying the specific mechanisms by which historical experiences are transmitted to future generations. While individuals may transmit their experiences to their children or even grandchildren, family socialization can hardly explain why historical patterns sometimes persist over several centuries. As Neundorf and Pop-Eleches 2019: 5 argue: "the study of the mechanisms underlying the production and reproduction of these legacies is still in its infancy." These authors emphasize the role of "socialization agents," from the macro-level of the state to the micro-level of the family, including the meso-level of social organizations such as churches or unions.

This paper argues that these meso-level organizations indeed play a crucial role for long-term persistence. After all, a regionally specific set of attitudes will only endure if it is transmitted both vertically, from one generation to the next among the long-term inhabitants of a region, and horizontally, to people whose ancestors did not yet share these attitudes, in particular in regions with a lot of migration.

Civil-society organizations are well positioned to generate both forms of transmission. Compared to microor macro-level socialization agents, they can better ensure a vertical transmission since they are typically more enduring than individual families and outlast specific political regimes. The prime example of this persistence are Churches, but it also characterizes unions or even political parties. Moreover, civil society organizations are well positioned to transmit attitudinal legacies horizontally to individuals whose own ancestors did not live in a region. The children of newcomers, for example, may pick up a regionally specific set of attitudes through their integration in civil society organizations. Again, Churches with their traditionally prominent role in education are a prime example of this mechanism.

Indeed, several studies have already shown that organized religion in general, and Catholicism in particular, can be a source of persistent socialization effects (Pop-Eleches and Tucker 2017). Jason Wittenberg 2006, 
for example, has analyzed how the Hungarian Catholic Church reinforced and protected traditional partisan affiliations, which then reemerged once Communism had been dismantled. Here, I go beyond these studies, which focus on Communism in Eastern Europe, by analyzing persistence over a much longer timespan of about 150 years. Moreover, my argument does not focus on the Church itself but on the lay-based civil society organizations at the heart of the Catholic milieu.

\section{The empirical case: support for the Alternative für Deutschland}

The empirical case I use to study the persistent effects of meso-level organizations is the regionally differentiated success of the radical right Alternative für Deutscbland in former West Germany. West Germany is a good case for studying these effects, since neither macro- nor micro-level factors are likely to explain long-term legacies. On the macro-level, West Germany experienced four different political regimes over the last 150 years. On the micro-level, there was a lot of internal migration, in particular after 1945 (Cantoni, et al. 2019), which makes it unlikely that legacies can be explained by transmission in the family alone.

The rise of the AfD in a country that long seemed to be immune against the radical right has, naturally, attracted a lot of attention. Most analyses of this phenomenon follow the broader literature on the reasons for the success of radical right parties by focusing on one of two main explanatory approaches: an economic approach, which argues that "modernization losers" are the basis for these parties' electoral support, and a cultural approach, which attributes their success to a "cultural backlash" (Inglehart and Norris 2016, Gidron and Hall 2017, Colantone and Stanig 2018). As a growing number of studies have argued, however, such general approaches need to be complemented with regionally differentiated explanations that are sensitive to the role of social context (McNamara 2017, Fitzgerald 2018, Harteveld, et al. 2018).

The existing literature on the AfD also points to the importance of historically determined regional context effects. For example, Richter and Bösch 2017: 12 find that the AfD was particularly strong where the rightwing extremist NPD had performed best in 2013 and conclude that a "specific political-cultural climate...promotes the success of the AfD in these districts". Similarly, Bergmann, et al. 2018 identify four socio-economically very different regional AfD strongholds and conclude that the AfD's success results "more strongly from - probably cultural or historical - differences between the respective regions than from economic indicators" (2018: 261). ${ }^{3}$

These studies demonstrate that an explanation of the AfD vote should account for regional differences with deep historical roots. At the same time, they also point to an important research gap: While they measure historical persistence, they often fail to explain it, instead attributing it to rather vacuous "cultural" factors. By looking more closely at the oppression and political mobilization of Catholics as a specific historical mechanism, this study thus aims to help fill this gap.

\footnotetext{
${ }^{3}$ All translations from German are my own.
} 


\section{Catholicism and radical right voting}

That Catholicism may be a factor that inhibits people from voting for the extreme right is a prominent hypothesis in the German context. It typically builds on the observation that Catholics were particularly reluctant to support the NSDAP (Falter 1991). Since AfD results correlate with historical NSDAP results (Cantoni, et al. 2019), this would suggest that Catholicism could play an important role in explaining the AfD's regionally differentiated success. However, recent research on Catholic voting in the 1930s suggests that it was driven by the clergy. As Spenkuch and Tillmann 2018 show, Catholics did not support the NSDAP only when being instructed to do so by the local priest. This mechanism is unlikely to be at work today, since priests and bishops hardly have a strong and immediate effect on Catholics' voting behavior anymore.

Without such direct influence of the church, it is not clear a priori whether Catholics would be more or less likely to vote for authoritarian or radical right parties. On the one hand, Catholicism can be seen as having a natural affinity with illiberal and authoritarian politics, since they share an emphasis on hierarchy and tradition (Whyte 1981, Bruce 2003, Minkenberg 2018). On the other hand, Catholicism can also be seen as providing a bulwark against such politics by creating a strong attachment to Christian Democratic Parties (Minkenberg 2018) and by fostering values of solidarity and compassion (Siegers and Jedinger 2020). Indeed, comparative studies of European countries have found that religiosity can work as a "vaccine" against radical right voting (Arzheimer/Carter 2009). At the same time, it is possible that Catholics become more susceptible to anti-immigrant/anti-muslim agitation as church attendance and the "religious integration" of Catholics declines (Immerzeel, et al. 2013, Meyer 2013).

Indeed, existing empirical studies of Catholic support for the AfD have generated inconsistent findings. While analyses based on individual-level survey data have found that Catholics are less likely to support the AfD (Arzheimer and Berning 2019, Siegers and Jedinger 2020), studies based on regional election results have not found any correlation between Catholicism and AfD vote shares (Richter and Bösch 2017, Jäckle, et al. 2018).

My argument is that these disparate results can be explained by considering the historical development of political Catholicism in Germany. Specifically, I argue that there was strong regional variation in the intensity of Catholic oppression by the state, that this variation triggered differences in the intensity of Catholic counter-mobilization, and that these differences still affect voting behavior today. I briefly explain each of these arguments in turn. 


\section{Historical background: state-church conflict in $19^{\text {th }}$ century Germany}

After the Reformation, there remained two majority Catholic regions in Germany: most parts of Southern Germany, including Bavaria; and large parts of Western Germany, including the Rhineland and Westphalia. The latter regions became part of Prussia after the Congress of Vienna. This had major consequences for the intensity of state-church conflict and the political mobilization of Catholics in the different regions. In particular, the conflict between state and Catholic Church was much more severe within Prussia than outside of it.

This conflict between the Catholic Church and the Prussian state saw several outbursts over the entire $19^{\text {th }}$ century. It reached an initial peak during the so-called Cologne troubles (Kölner Wirren) in the late 1830s. The Archbishop of Cologne was imprisoned for 18 months over a conflict about religiously mixed marriages. This triggered a series of riots in Rhineland and Westphalia, and more generally a political mobilization of Catholics as Catholics - something that had not been seen before (Lönne 1986). In 1852, a Catholic parliamentary group was established in the Landtag of Prussia.

The single most important conflict between Church and state, however, was the so-called Kulturkampf, which raged on between 1871 and 1887 but had its most dramatic phase between 1871 and 1875 . While this struggle affected the entire German empire, it was much more intense within Prussia than outside of Prussia (Ross 1998, 6, Strötz 2005, 211ff., 245). In particular the "May laws," through which the state sought to gain direct influence over the selection of priests and bishops, were restricted to Prussia and some of Prussia's smaller neighboring states. The Prussian state also closed the Catholic seminaries (Strötz 2005, 308), temporarily imprisoned five bishops (Ross 1998, 58), and forced several thousand priests and members of religious orders into - often Bavarian - exile.

\section{The formation of the Catholic milieu}

These differences in the intensity of political conflict led to major differences in political mobilization. In response to their oppression, Prussian Catholics developed a dense network of Catholic clubs, associations, Catholic newspapers, educational activities, and a strong attachment to the Catholic party (Arbeitskreis für kirchliche Zeitgeschichte 2000). This dense network is known as the Catholic "milieu" (Lepsius 1966). But while literature in political sociology has often implicitly assumed a single homogenous Catholic milieu in the Catholic regions of the German empire, more recent historical research has clarified that the quintessential Catholic milieu only existed in Prussia, and even there it was not fully developed in all regions. According to a systematic review of historical studies of political Catholicism (Arbeitskreis für kirchliche Zeitgeschichte 2000), a full-fledged Catholic milieu developed mainly in Westphalia, the northern Rhine Province, and the southwestern part of today's Lower Saxony. In Southern Germany, by contrast, there dominated a more traditional, Church-focused form of Catholic mobilization. Finally, there was no strong formation of Catholic activities in regions where less than $15-20 \%$ of the population was Catholic. 
These differences in the formation of the Catholic milieu also affected the two politically most important forms of Catholic organization: Catholic associations and the Catholic party. At the association level, this is demonstrated by the katholischer Verein Deutschlands, which organized the Katholikentag festivals and was the “most important vehicle for mobilizing popular dissent against Bismarck's ecclesiastical policies" (Ross 1998: 129). While the organization aimed for nationwide mobilization,

„membership varied a good deal from region to region [...] most Bavarian Catholics were too particularistic to unite in a common enterprise of this sort with their coreligionists north of the Main River. The association also met with little success in expanding its membership in southwestern Germany" (ibid.)

Similarly, the biggest Catholic association, the Volksverein für das katholische Deutschland (People's Association for Catholic Germany), which aimed to promote Catholic education and Christian social reforms and attracted up to 800,000 members before World War I, had the majority of its members in Westphalia and the Rhine Province (Heitzer 1979, Klein 1996).

At the party level, the Catholic Centre Party always displayed weak national organization, in particular in comparison to the Social Democrats (Nipperdey 1961). The Party's Reichstag faction was more a collection of representatives from different regional parties than a coherent national party. Indeed, its Bavarian branch - the Bavarian Patriots' Party - did not change its name to the Bavarian Centre Party until 1887. Its interwar successor, the Bavarian People's Party (BVP), dissolved the joint parliamentary faction with the Centre Party in 1920. In the presidential election of 1925, the BVP even supported the national-conservative candidate Hindenburg instead of the Rhenish Centre politician Marx.

Historical literature thus clearly shows that an organized and politically strongly mobilized Catholic milieu mainly emerged in the Prussian part of Germany. Here, political Catholicism developed in the form of the mobilization of societal actors against the state. It was deeply interwoven with society through a network of associations and the Centre Party and it opposed an authoritarian state. Moreover, as Margaret Anderson 1986 argues, the experience of the Kulturkamp $f$ and the political reaction to it led to an emancipation of Catholic laity from the Church hierarchy. Outside of Prussia, by contrast, political Catholicism developed as a Church-affiliated clerical movement with much weaker lay associations and was represented by a political party much more closely associated with the Church.

\section{The Catholic milieu as mechanism of historical transmission}

My argument is that the formation of the Catholic milieu provides the mechanism by which historical experiences of political oppression were transmitted to later generations. Individual Catholics died, but the organizations they had created lived on. Indeed, milieus - not just the Catholic milieu but also the socialdemocratic milieu - have had a crucial influence on the development of the German party system (Lepsius 1966). According to Lösche and Walter 2000, 472, within these milieus "the experiences of primary conflicts 
were saved, intergenerationally bequeathed and organizationally solidified". Hence, they still affected voting behavior long after the original conflicts during which they were formed had been assuaged. Although the classical Catholic milieu has largely disappeared since the 1960s (Lösche and Walter 2000, Ziemann 2000), its remnants still affect political behavior, as is evidenced by the fact that the religious cleavage still carries weight in explaining German election results (Elff and Rossteutscher 2011).

Thus, the political mobilization of Catholics in the $19^{\text {th }}$ century may still affect voting behavior today. In those regions where Catholics historically mobilized through a Catholic milieu and where Catholics are still socialized in the remainders of this milieu, they should be much more reluctant to support the AfD for several reasons. Firstly, the milieu historically created a strong attachment to a Christian party. Indeed, between 1871 and 1933, the Centre Party commanded more than 50\% - and up to 80\% - of the Catholic vote. Since World War II, Catholics have over-proportionally supported the supra-confessional Christian Democrats, who still have their best election results in the former strongholds of the Centre Party. Secondly, remainders of the milieu such as Catholic sports clubs and other Catholic associations provide a form of social capital that is often seen as fostering democratic values and as inhibiting people from voting for the radical right (Putnam 1993, Coffé, et al. 2007, but see Rydgren 2009). Finally, since the milieu emerged during conflict with an authoritarian government, milieu socialization may also foster a skepticism toward authoritarian politics in general. Moreover, since a milieu forms an important social context even for former Catholics or non-Catholics, they may also refrain from voting AfD. In other words, the milieu may have worked not only as a mechanism of vertical, but also of horizontal transmission.

Where milieu-based lay movements played a smaller role in the development of political Catholicism by contrast, its anti-authoritarian effect was much weaker as it depended entirely on the Church. To put it provocatively: Not voting for authoritarians was in itself an expression of obeying an authority. When the Church lost its willingness or capacity to inhibit Catholics from voting for authoritarians, the inhibiting effect of Catholicism disappeared. Hence, Catholics in these regions should be much more open toward supporting the AfD.

\section{Data and Empirical Strategy}

To test this argument, my empirical analysis proceeds in two steps. I first analyze the results of the German federal election of 2017 and show that the strength of the AfD differs between Catholic regions which have experienced high and low levels of oppression, even when controlling for a battery of economic and sociodemographic factors. Afterwards, I study the organizational strength of the Catholic milieu in the early $20^{\text {th }}$ and early $21^{\text {st }}$ century and show that the empirical pattern of Catholic voting today can indeed be explained by differences in the historical mobilization of political Catholicism.

Since a milieu is a social entity, I conduct most of my analyses on the regional level, studying municipallevel election results. There are more than 8,000 municipalities in West Germany, allowing me to study 
election outcomes on a fine-grained geographical level. The dependent variable in these analyses is the share of AfD votes among all (valid) votes cast in the municipality.

I restrict my analysis to former West Germany for two main reasons. First, there are simply very few Catholics in former East Germany, hence, Catholicism can hardly contribute to explaining voting behavior in the East. More importantly, any mechanism of historical persistence was severely disrupted in East Germany, as the combined effect of 56 years of fascist and socialist rule was to systematically dismantle existing milieus, their party structures, as well as their civil society foundations.

In the first part of the analysis, I focus on the persistent effect of oppression. The main independent variable in this analysis is the interaction between the Catholic population share and different measures of historical oppression. As control variables, I include several potential explanatory factors which may correlate with Catholicism. The socio-structural composition of the municipality is measured by the total size of the population and the population shares of foreigners, women, and of people older than 65 . To account for local economic structures, I control for the unemployment rate, the share of regular employment, the employment share of manufacturing, and the local share of low-wage employees (see Appendix A for descriptive statistics). I also add a dummy for universities (data from Apfeld 2019). Finally, a dummy for municipalities within 30 kilometers of the Austrian or Czech border controls for the argument that the AfD performs best in those regions where the most refugees arrived in 2015 (Jäckle, et al. 2018), which also happen to be highly Catholic.

In all regression models, I weight observations by the number of voters in the municipality. To control for spatial correlation across municipalities, I estimate Conley standard errors with a cutoff of $50 \mathrm{~km}$ using the procedure developed by Colella, et al. 2019. Results are robust to varying the cutoff (see Appendix B). I include state-fixed effects to ensure that the results are not driven by institutional or other differences between German states that emerged after 1945. Moreover, I also replicate the analysis solely for the state of Rhineland-Palatinate. This state was created after World War II by merging a formerly Prussian North with a non-Prussian South and thus enables me to test my hypothesis while holding all state-level institutions constant. In a further step, I restrict my analysis to the historical border region within Rhineland-Palatinate, increasing the comparability of the treated and untreated regions even more.

Finally, I also study individual attitudes toward the AfD to address concerns of an ecological fallacy. I use data from the German Longitudinal Election Study (GLES), which contains information on the electoral district in which people live and thus allows me to link their expressed attitudes to the level of historical oppression and historical Catholic mobilization in their region.

\section{Measuring historical oppression}

I use two measures of historical oppression. The broader and more general measure is whether a municipality historically belonged to Prussia, since Prussia was the German state in which the conflict with 
the Catholic Church was most severe. This measure does not rely on a specific point in time, but captures an entire history of state-church conflict. However, it does not distinguish its intensity within Prussia, nor does it differentiate between non-Prussian states at all.

To create a more fine-grained measure of oppression, I collected data on the intensity of the Kulturkampf, the single most important confrontation between the German state and the Catholic Church in the 19th century. The historical literature agrees that the Kulturkampf was most intense within Prussia but does not provide quantifiable measures of its regional intensity. To approximate such a measure, I rely on a contemporary newspaper source: between January 1875 and March 1876, the Frankfurter Zeitung published a bi-weekly "Kulturkampf Kalender" in which it listed oppression events of the previous weeks.

In total, the newspaper catalogued more than 1,200 instances of state oppression in the German empire. Of these, 767 took place in West Germany. While about a third of these entries report measures taken against Social Democrats or against the secular press, 499 refer to cases of the oppression of Catholics. While some entries include the specific municipality of the event, most refer to court decisions which identify the administrative district of the court (see Appendix A). I thus construct a regional index of Kulturkampf intensity on the administrative district level.

To create this index, I match the event data with the local number of Catholics. I have data on the Catholic population per district for 1871 and 1880 and estimate the number of Catholics in 1875 using the average annual growth rate between 1871 and 1880. In total, there are 47 such districts in West Germany. To create an index of regional oppression, I count the number of oppression events per 100,000 Catholics in each district and take the log of this quotient to prevent districts with very few Catholics from having an outsized influence. I thus estimate:

Intensity $=\ln \left(1+\frac{100,000 * \text { no. of oppresion events }}{\text { no. of Catholics in district }}\right)$

Figure 2 (left panel) shows the regional distribution of this index. The pattern that emerges is reassuringly similar to the characterization of the Kulturkampfin the historical literature. Only taking into account districts with at least 10 oppression events, the Kulturkampf was most intense in the Prussian district of Kassel, followed by the Prussian districts of Minden and Düsseldorf. Apart from Protestant regions, the intensity was lowest in Bavaria and the Kingdom of Württemberg.

In the following analyses, I rely on both measures of oppression: the index of Kulturkampf intensity as well as whether a municipality belonged to Prussia. The former measure has the advantage that it is more geographically fine-grained and based on actual oppression events. However, it only provides a snapshot from 1875-76. Whether or not a municipality belonged to Prussia better captures the entire history of Catholic oppression in the $19^{\text {th }}$ century but does not provide regional differentiation. Reassuringly, both measures generate very similar results. 

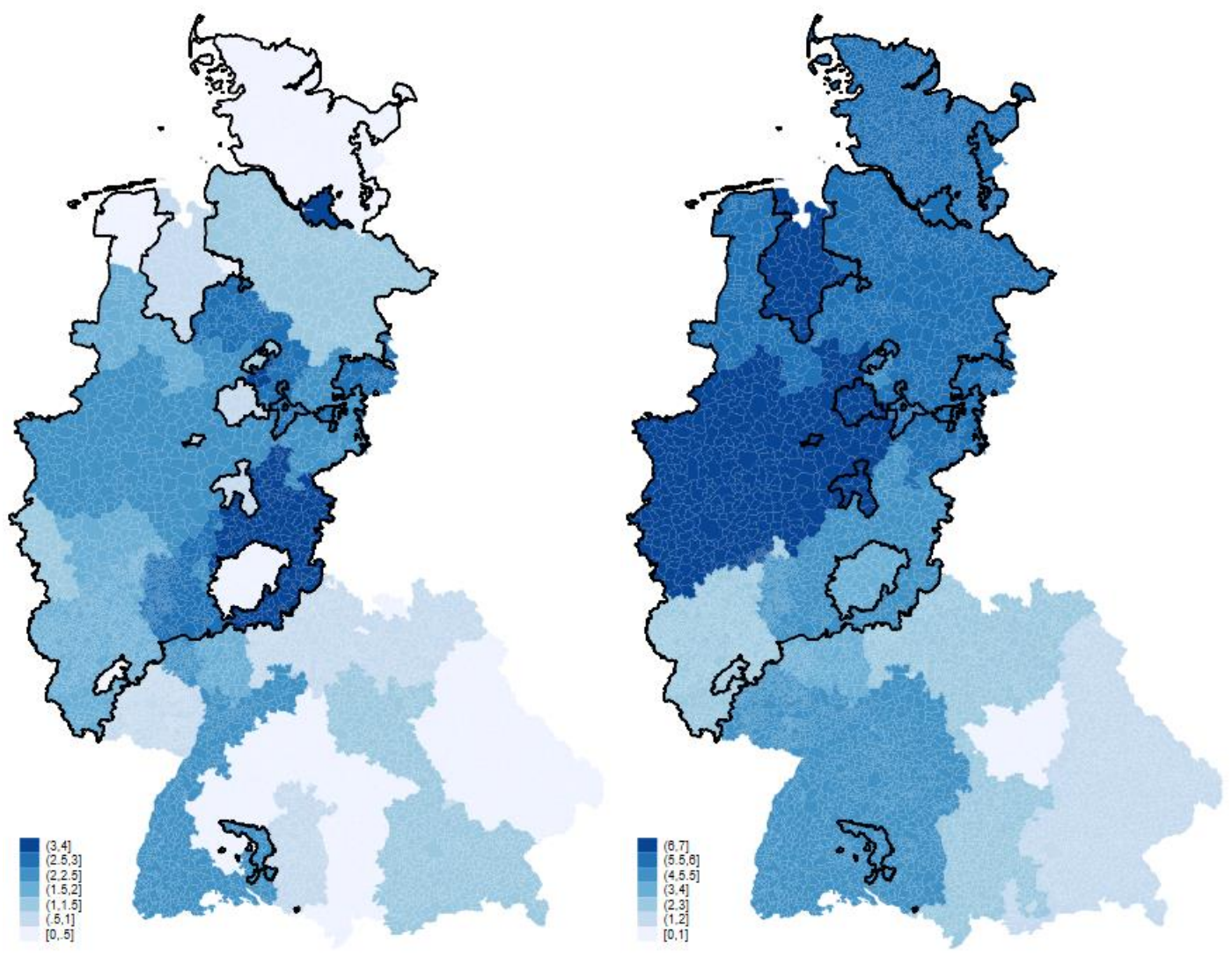

Figure 2: Intensity of Kulturkampf and share of Catholics with Volksverein membership in 1913

\section{Measuring Catholic mobilization}

In the second step of my analysis, I study the mechanism that connects historical oppression to contemporary electoral outcomes and seek to show that this effect is driven by differences in Catholic mobilization. To measure Catholic mobilization, I use the strength of Catholic associations at the beginning of the $20^{\text {th }}$ century. I use data on the regional membership of the aforementioned Volksverein für das katholische Deutschland, the largest Catholic association, which was founded in 1890. I have membership data for 1913 and 1928 from the books by Heitzer (1979) and Klein (1996). The data for 1913 are collected on the diocese level, the data for 1928 on the state or province level. At both points in time, the Volksverein consistently organized a higher share of the Catholic population within Prussia than outside of Prussia (Figure 2, right panel).

A contemporary measure of what remains of the Catholic milieu is the participation in the bi-annual Katholikentag festivals, the biggest gathering of German Catholics. ${ }^{4}$ During the German Empire, these festivals were manifestations of Catholic opposition to Prussian oppression. They therefore have their roots in the mobilization of the Catholic milieu, even if they have acquired a more event-like character today. The

\footnotetext{
${ }^{4}$ I have also collected data on membership in Catholic associations, but their regional patterns differ substantially between associations and it is unclear to what extent these differences already emerged in the $19^{\text {th }}$ century.
} 
last Katholikentag in Münster had about 90,000 participants. Katholikentag participation is a good indicator of the persistent strength of the Catholic milieu since participants often do not attend individually, but in groups organized by local chapters of Catholic associations. Their ability to mobilize participants for the Katholikentag thus proxies the more general strength of Catholic lay organizations.

The organizing committee of the Katholikentag festivals provided me with data on the number of participants from each German diocese at the last 7 Katholikentag festivals. To calculate the average degree of participation by diocese, I divide the share of participants from a diocese by the share of German Catholics living there. Since participation strongly varies with geographic distance from the festival location, I exclude the highest and the lowest participation rate for each Diocese. ${ }^{5}$ The relationship between the average share of participants and the share of Catholics ranges from a minimum of 0.18 in the Bavarian diocese of Passau to a maximum of 1.77 in the formerly Prussian diocese of Osnabrück.

\section{Empirical Analysis}

\section{West Germany}

I first analyze the relationship between Catholicism, oppression, and AfD vote shares in all of West Germany. When looking at the share of Catholics in isolation, there is no correlation to AfD votes (Table 1, Model 1). However, when interacted with my simplest measure of oppression - whether a municipality historically belonged to Prussia - Catholicism has a strong effect, which works in opposite directions within and outside of Prussia (Model 2). This effect becomes slightly weaker when control variables are included but remains substantively important (Model 3). Finally, I estimate two separate regressions for the formerly Prussian and non-Prussian parts of the country. This allows the effects of the control variables to differ between the two regions. Confirming the earlier findings, the relationship between Catholicism and AfD voting is significant and negative in Prussian regions (Model 4). By contrast, outside of former Prussia, if anything it is positive, although the association is not significant (Model 5).

\footnotetext{
5 The festivals were spread across Germany. One took place in East Germany (Leipzig), three in formerly Prussian cities in West Germany (Münster, Osnabrück, Saarbrücken), and three in West German cities which never belonged to Prussia (Regensburg, Mannheim, Ulm).
} 


\begin{tabular}{|c|c|c|c|c|c|c|}
\hline & $\begin{array}{c}\text { (1) } \\
\text { Catholic }\end{array}$ & $\begin{array}{c}(2) \\
\text { Interact }\end{array}$ & $\begin{array}{c}\text { (3) } \\
\text { Full Model }\end{array}$ & $\begin{array}{c}\text { (4) } \\
\text { Prussia }\end{array}$ & $\begin{array}{c}(5) \\
\text { Non } \\
\text { Prussia }\end{array}$ & $\begin{array}{c}\text { (6) } \\
\text { Intensity }\end{array}$ \\
\hline Share Catholics & $\begin{array}{l}-0.012 \\
(0.013)\end{array}$ & $\begin{array}{l}0.030+ \\
(0.016)\end{array}$ & $\begin{array}{l}0.022+ \\
(0.012)\end{array}$ & $\begin{array}{c}-0.032 * * \\
(0.011)\end{array}$ & $\begin{array}{c}0.018 \\
(0.012)\end{array}$ & $\begin{array}{l}0.030^{*} \\
(0.015)\end{array}$ \\
\hline Prussia & & $\begin{array}{c}1.399 * * \\
(0.493)\end{array}$ & $\begin{array}{c}1.233^{* * *} * \\
(0.361)\end{array}$ & & & \\
\hline Prussia $\times$ Catholic & & $\begin{array}{c}-0.081 * * * \\
(0.019)\end{array}$ & $\begin{array}{c}-0.057 * * * \\
(0.014)\end{array}$ & & & \\
\hline Kulturkampf intens & & & & & & $\begin{array}{c}0.656^{*} \\
(0.270)\end{array}$ \\
\hline Kulturkampf x Cath & & & & & & $\begin{array}{c}-0.026^{* *} \\
(0.009)\end{array}$ \\
\hline Unemployment & & & $\begin{array}{c}1.216^{* * *} \\
(0.157)\end{array}$ & $\begin{array}{c}1.000^{* * *} \\
(0.172)\end{array}$ & $\begin{array}{c}1.485^{* * *} \\
(0.214)\end{array}$ & $\begin{array}{c}1.235^{* * *} \\
(0.165)\end{array}$ \\
\hline Low-wage empl & & & $\begin{array}{c}-0.339 * * * \\
(0.094)\end{array}$ & $\begin{array}{c}-0.453^{* * *} \\
(0.107)\end{array}$ & $\begin{array}{l}-0.183 \\
(0.147)\end{array}$ & $\begin{array}{c}-0.324 * * \\
(0.103)\end{array}$ \\
\hline Manufact empl & & & $\begin{array}{c}0.012^{* *} \\
(0.004)\end{array}$ & $\begin{array}{l}0.014^{*} \\
(0.006)\end{array}$ & $\begin{array}{l}0.011^{*} \\
(0.005)\end{array}$ & $\begin{array}{l}0.010^{*} \\
(0.004)\end{array}$ \\
\hline Regular empl & & & $\begin{array}{c}0.183^{* * *} \\
(0.037)\end{array}$ & $\begin{array}{c}0.087+ \\
(0.050)\end{array}$ & $\begin{array}{c}0.233^{* * * *} \\
(0.033)\end{array}$ & $\begin{array}{c}0.181^{* * *} \\
(0.038)\end{array}$ \\
\hline Population & & & $\begin{array}{c}-0.002^{* * *} \\
(0.000)\end{array}$ & $\begin{array}{c}-0.003^{* * *} \\
(0.001)\end{array}$ & $\begin{array}{c}-0.002^{* * *} \\
(0.001)\end{array}$ & $\begin{array}{c}-0.002^{* * *} \\
(0.000)\end{array}$ \\
\hline University & & & $\begin{array}{c}-1.750^{* * *} \\
(0.330)\end{array}$ & $\begin{array}{c}-1.137^{*} \\
(0.498)\end{array}$ & $\begin{array}{c}-2.350^{* * *} \\
(0.408)\end{array}$ & $\begin{array}{c}-1.860 * * * \\
(0.350)\end{array}$ \\
\hline Share Foreigners & & & $\begin{array}{c}0.007 \\
(0.034)\end{array}$ & $\begin{array}{l}-0.006 \\
(0.045)\end{array}$ & $\begin{array}{c}0.007 \\
(0.045)\end{array}$ & $\begin{array}{l}-0.000 \\
(0.034)\end{array}$ \\
\hline Population > 65 & & & $\begin{array}{c}0.050 \\
(0.033)\end{array}$ & $\begin{array}{c}0.057 \\
(0.044)\end{array}$ & $\begin{array}{c}0.032 \\
(0.047)\end{array}$ & $\begin{array}{c}0.038 \\
(0.034)\end{array}$ \\
\hline Female Pop Share & & & $\begin{array}{c}-0.427 * * * \\
(0.100)\end{array}$ & $\begin{array}{c}-0.452^{* *} \\
(0.166)\end{array}$ & $\begin{array}{c}-0.396^{* * * *} \\
(0.069)\end{array}$ & $\begin{array}{c}-0.426 * * * \\
(0.105)\end{array}$ \\
\hline Close to border & & & $\begin{array}{l}1.576+ \\
(0.807)\end{array}$ & & $\begin{array}{l}1.611+ \\
(0.832)\end{array}$ & $\begin{array}{l}1.632^{*} \\
(0.793)\end{array}$ \\
\hline Constant & $\begin{array}{c}8.395^{* * *} \\
(0.392) \\
\end{array}$ & $\begin{array}{c}7.348^{* * *} \\
(0.618) \\
\end{array}$ & $\begin{array}{c}21.230^{* * *} \\
(5.687) \\
\end{array}$ & $\begin{array}{c}28.809^{* *} \\
(9.041) \\
\end{array}$ & $\begin{array}{c}16.851^{* * *} * \\
(4.093) \\
\end{array}$ & $\begin{array}{c}22.212^{* * *} * \\
(5.917) \\
\end{array}$ \\
\hline $\mathbf{N}$ & 8369 & 8369 & 8100 & 3939 & 4161 & 8100 \\
\hline r2 & 0.430 & 0.477 & 0.642 & 0.512 & 0.675 & 0.638 \\
\hline
\end{tabular}

All models contain state fixed effects. Conley standard errors with a cutoff at $50 \mathrm{~km}$ in parentheses. $+\mathrm{p}<0.10 * \mathrm{p}<0.05, * * \mathrm{p}<0.01, * * * \mathrm{p}<0.001$

Table 1: AfD vote share on the municipal level 2017, West Germany

Based on Model 3, Figure 3 shows how strongly the predicted AfD share diverges with a growing share of Catholics. While this predicted share is almost identical for municipalities with few Catholics, the predicted AfD result in Prussian municipalities becomes significantly lower than the result in non-Prussian municipalities when the share of Catholics reaches 40 percent. As the median municipality in West Germany has a Catholic share of 35.1 percent, this affects a substantial number of municipalities. 


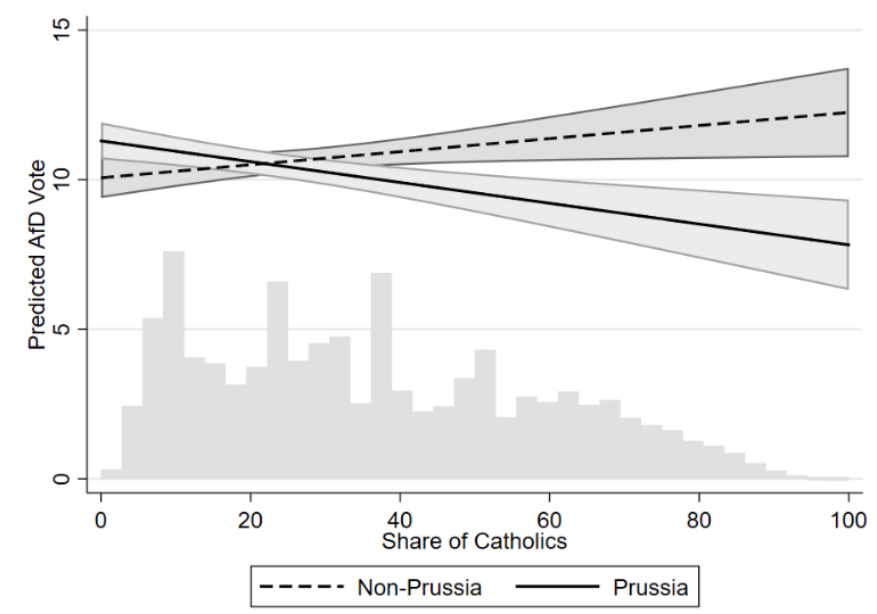

Figure 3: Predicted AfD vote share in municipalities within and outside of former Prussia ${ }^{6}$

Finally, I use my index of Kulturkampf intensity in Model 6 as a more fine-grained measure of historical oppression. That is, I effectively replicate Model 3 but replace the Prussia dummy with the more fine-grained measure of regional oppression and cluster standard errors at the level at which oppression is measured (these errors are slightly more conservative than Conley standard errors, see Appendix B).

As the analysis shows, there is indeed a significant interaction between the regional intensity of the Kulturkampf and the Catholic population share today. In regions where the historical oppression of Catholics was strong, the Catholic population share is negatively related to AfD vote shares. In regions where oppression was weak, by contrast, Catholic population shares and AfD performance are not significantly related (see Figure 4).

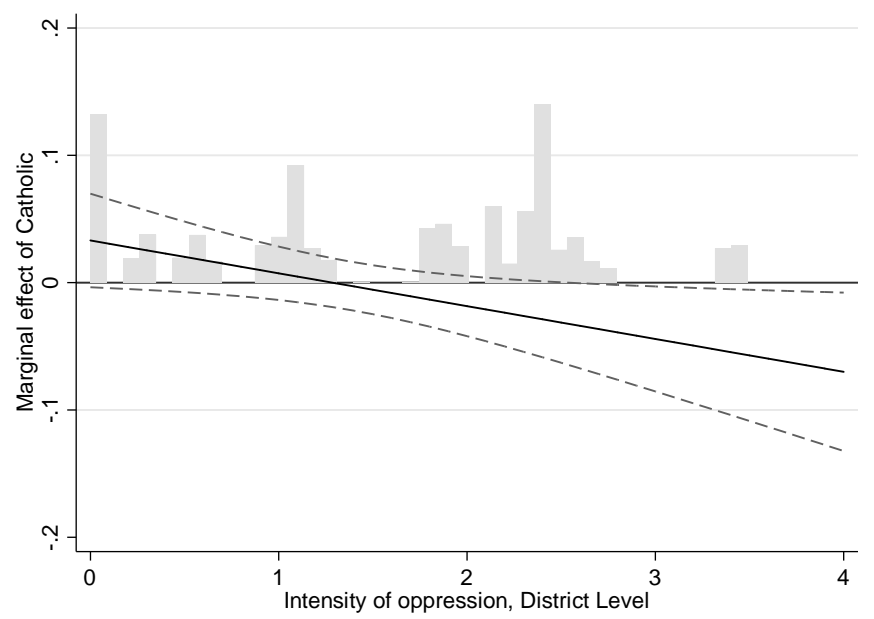

Figure 4: Intensity of Kulturkampf and marginal effect of Catholicism on AfD vote share ${ }^{7}$

\footnotetext{
${ }^{6}$ The histogram shows the share of West German voters living in municipalities with a certain share of Catholics.

7 The histogram shows the share of West German voters living in municipalities that experienced a certain level of oppression.
} 
In Appendix C, I provide additional robustness checks. I replicate the regression for those 2,700 municipalities in which Catholics represent at least two-thirds of the population in order to reduce the risk of an ecological fallacy. In this analysis of very Catholic regions, the estimated effect of Catholicism remains statistically significant and becomes substantively greater. Moreover, I study whether the effect of Prussian rule also holds for former East Germany. As expected, there is no such effect. In fact, there is a weak negative direct effect of Catholicism, but no significant difference between Prussian and non-Prussian Catholics.

In summary, these analyses show that those Catholic regions where Catholics were oppressed during the $19^{\text {th }}$ century have been much more resistant to the AfD than Catholic regions where little oppression occurred. Socio-demographic and labor-market related differences cannot explain these regional patterns.

\section{Rhineland-Palatinate}

The models presented so far included state-fixed effects to control for the possibility that idiosyncratic differences between German states that occurred after 1945 are the true reason behind the apparent Prussia effect. A second concern is that Catholic regions may have already differed before they experienced oppression, that is before 1815, and that my analysis simply picks up these differences. In order to tackle these issues, I seek to analyze two regions where Catholics experienced few systematic differences before 1815 , were subjected to a very different treatment after 1815 , and became embedded in the same institutional context after 1945. The best candidate for such a region is the former Prussian-Bavarian border region in the state of Rhineland-Palatinate, which was created as a "Bindestrich-Bundesland" (hyphen-state) after World War II.

The area that came to be Rhineland-Palatinate consisted of dozens of independent territories before the French revolution and was occupied by France between 1794 and 1815. After the congress of Vienna, the northern part of the state (today: 2.1 million inhabitants) became part of Prussia, the southern part (today: 1.4 million inhabitants) was allocated to Bavaria and the Eastern region around today's state capital of Mainz (today: 600,000 inhabitants) went to Hesse-Darmstadt. Moreover, three smaller German states were guaranteed territorial compensation for losses or unfulfilled promises in other parts of Germany. The necessary territories were taken from the region between the Prussian and the Bavarian territories. The size of these compensations was defined by the number of inhabitants: Oldenburg received a territory with 20,000 inhabitants and so on. Hence, borders were drawn to create the necessary numbers and did not necessarily respect historical attachments. With the exception of the Oldenburgian territory of Birkenfeld, these territories later went to Prussia. The Duke of Saxe-Coburg-Saalfeld sold his territory to Prussia in 1834, while the Homburgian territory of Meisenheim was annexed in 1866. These transactions generated the longest portion of the border between Prussia and Bavaria. This history suggests that the borders that 
emerged in the $19^{\text {th }}$ century did not follow any systematic pre-existing differences in the behavior or treatment of Catholics. ${ }^{8}$

However, Catholics were treated very differently after 1815, since they were a minority in Prussia and a dominant majority in Bavaria. In Hesse-Darmstadt, the third major region of the state, they also experienced heavy oppression. In fact, according to my measure of oppression, the Kulturkampf was even more intense in this region than in the Prussian areas of the state. Wilhelm Emmanuel von Ketteler, the Bishop of the Hessian diocese Mainz from 1850 to 1877, was one of the most prominent Catholic opponents of Bismarck and was imprisoned for two years starting in 1873.

In summary, Rhineland-Palatinate is a good test case because Catholics in the northern and in the southern part of the state were arguably not treated systematically differently before 1815 , were treated very differently between 1815 and 1933, and were then again treated equally after 1945. Finally, there is enough variation in the share of Catholics in both the Prussian and non-Prussian part of the state to allow the estimation of an interaction effect.

Figure 5 strongly suggests that the results in West Germany as a whole also apply to Rhineland-Palatinate: The AfD received its highest vote shares in the Bavarian Palatinate and its lowest vote shares in the most Catholic areas of the former Prussian Rhine Province. I provide more systematic evidence for this relationship in two steps. First, I replicate the analyses from above just for this state. Afterwards, I restrict my analysis to the immediate region along the historical Prussian-Bavarian border in order to exploit the discontinuity in the treatment of Catholics that occurred at this border.
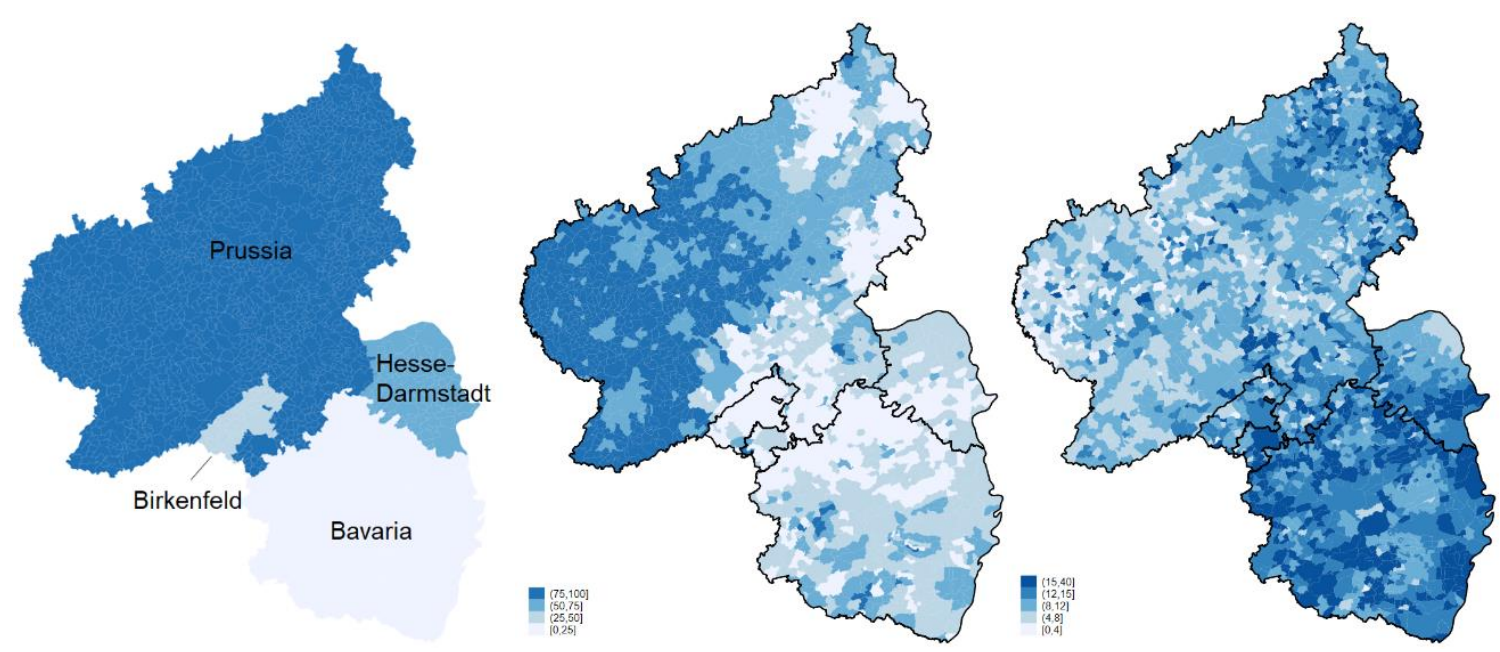

Figure 5: Rhineland-Palatinate in 1866, Catholic share in 2011 and AfD vote share in 2017

Table 2 reports the same regressions as already presented, just restricted to Rhineland-Palatinate. In contrast to the analysis for West Germany, there is a strong direct negative correlation between Catholicism and the AfD vote. This is not unexpected, as Prussian Catholics alone constitute $61 \%$ of all Catholics in Rhineland-

${ }^{8}$ Diocesan borders were also redrawn to fit the new political borders. 
Palatinate, whereas they make up only $47 \%$ of all Catholics in West Germany. Together with the oppression of Hessian Catholics, this makes it more likely to find an aggregate negative effect.

Nevertheless, this direct effect masks important variation in the behavior of Catholics in different parts of the state. However, simply adding an interaction with Prussia, as in the analysis for West Germany, just splits the effect of Catholicism into an insignificant direct effect and another insignificant interaction effect (Model 2). Only looking at Prussian municipalities, however, Catholicism has a strong negative effect (Model 3). Outside of Prussia, Catholicism does not have an effect, which makes sense, given the highly disparate treatment of Catholics in Hesse and Bavaria. This suggests that the effect of Catholicism is not really about Prussia as such, but rather about the level of oppression. This is confirmed by a model that includes the continuous measure of Kulturkampf intensity (Model 5): The more intense the oppression, the greater the negative relationship between Catholicism and the AfD.

\begin{tabular}{|c|c|c|c|c|c|}
\hline & $\begin{array}{c}\text { (1) } \\
\text { Catholic }\end{array}$ & $\begin{array}{c}(2) \\
\text { Full Model }\end{array}$ & $\begin{array}{c}(3) \\
\text { Prussia }\end{array}$ & $\begin{array}{c}(4) \\
\text { Non } \\
\text { Prussia }\end{array}$ & $\begin{array}{c}\text { (5) } \\
\text { Kulturkampf }\end{array}$ \\
\hline Share Catholics & $\begin{array}{c}-0.088^{* * *} \\
(0.013)\end{array}$ & $\begin{array}{l}-0.025 \\
(0.021)\end{array}$ & $\begin{array}{c}-0.056^{* * *} \\
(0.008)\end{array}$ & $\begin{array}{l}-0.018 \\
(0.017)\end{array}$ & $\begin{array}{c}0.016 \\
(0.030)\end{array}$ \\
\hline Prussia & & $\begin{array}{l}-0.466 \\
(0.699)\end{array}$ & & & \\
\hline Prussia x Catholic & & $\begin{array}{l}-0.019 \\
(0.024)\end{array}$ & & & \\
\hline Kulturkampf intensity & & & & & $\begin{array}{l}-0.027 \\
(0.467)\end{array}$ \\
\hline Kulturkampf x Cath & & & & & $\begin{array}{l}-0.036 * \\
(0.017)\end{array}$ \\
\hline Controls & $\mathrm{NO}$ & YES & YES & YES & YES \\
\hline $\mathbf{N}$ & 2301 & 2119 & 1457 & 662 & 2119 \\
\hline r2 & 0.233 & 0.534 & 0.375 & 0.539 & 0.569 \\
\hline
\end{tabular}

Table 2: AfD vote share on the municipal level 2017, Rhineland-Palatinate

These analyses include all municipalities within the state. In a second step, I restrict my analysis to the immediate border region in order to further improve the comparability of Prussian and non-Prussian municipalities. Following the discussion above, I focus on the Prussian-Bavarian border, which emerged through a rather random historical process and separates two regions where Catholics were treated very differently. I thus replicate the analysis from above but restrict my analysis to the 355 municipalities within 25 kilometers of the Prussian-Bavarian border (excluding municipalities in former Birkenfeld or Hesse) and add an interaction with the distance to the border to the "Prussia x Catholic" interaction. The average municipality in this sample has a Catholic population share of $31 \%$ with a standard deviation of $14 \%$. Since I am interested in an interaction effect, I cannot set the cutoff much lower, as I would otherwise lose too much variation in the share of Catholics on the Bavarian side of the border. 
This is not a clean RDD, since the municipalities on both sides of the border are not statistically indistinguishable (those on the Prussian side are on average more Catholic, which may in itself be a treatment effect, see Appendix D), but it reduces the differences between municipalities as much as possible. Moreover, I am not interested in the direct effect of the historical state, but in the interaction effect between state and Catholicism.

I report the full model in the appendix. In Figure 6, I show the predicted values from this regression for a municipality with a Catholic population share one standard deviation below the mean (i.e. 17\%, left panel) and for a municipality with a Catholic population share one standard deviation above the mean $(45 \%$, right panel). As the figure shows, there is no discontinuity at the border for municipalities with a low share of Catholics. In municipalities with a high share of Catholics, by contrast, the predicted AfD result is considerably lower on the Prussian side of the border. There is thus evidence of a persistent effect of oppression even in a region that is as homogenous as possible and has been part of the same institutional structure for more than 70 years.
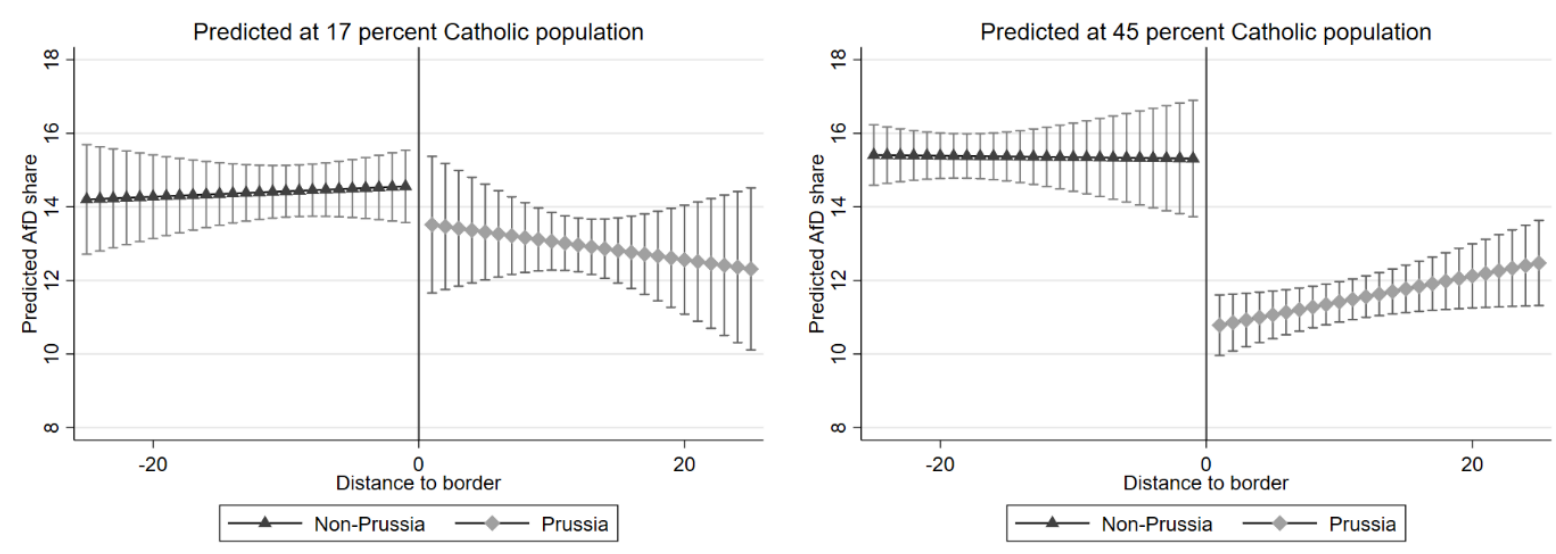

Figure 6: Predicted AfD support at low and high levels of Catholicism

\section{Evidence on the mechanism}

As the analyses have shown so far, there are substantial differences in the voting behavior between Catholic regions whose inhabitants have historically been subjected to high and low degrees of oppression. Can these differences indeed be explained by the disparate development of the Catholic milieu in the late $19^{\text {th }}$ and early $20^{\text {th }}$ century? To test this, I proceed in two steps. I first show that the historical intensity of regional oppression predicts the strength of Catholic mobilization. I then provide evidence that AfD vote shares in 2017 are systematically related to the strength of the Catholic milieu throughout the $20^{\text {th }}$ century.

To test whether the historical degree of oppression predicts the strength of Catholic mobilization, I regress my three measures of Catholic mobilization on my measure of Kulturkampf intensity (Table 3). Since Kulturkampf intensity is measured at the administrative district level, I also estimate the regression at this level. To make the results more comparable, I standardize dependent and independent variables. For all 
three measures, there is a significant association between the two measures. Indeed, Kulturkampf intensity explains around a quarter of the variation in the regional strength of Catholic mobilization.

\begin{tabular}{|c|c|c|c|}
\hline & $\begin{array}{c}(1) \\
\text { Volksverein } 1913 \\
\end{array}$ & $\begin{array}{c}(2) \\
\text { Volksverein } 1928\end{array}$ & $\begin{array}{c}(3) \\
\text { Katholikentage }\end{array}$ \\
\hline Kulturkampf & $\begin{array}{c}0.481 * * * \\
(0.123)\end{array}$ & $\begin{array}{c}0.490^{* * *} \\
(0.130)\end{array}$ & $\begin{array}{c}0.525 * * * \\
(0.119)\end{array}$ \\
\hline $\mathbf{N}$ & 53 & 47 & 53 \\
\hline $\mathrm{r} 2$ & 0.231 & 0.241 & 0.276 \\
\hline
\end{tabular}

Table 3: Association between Kulturkampf intensity and Catholic mobilization

To test whether the strength of the Catholic milieu in the early $20^{\text {th }}$ century indeed affects the voting behavior of Catholic regions today, I repeat the already familiar regression but interact the Catholic population share with the continuous measures of the strength of the Volksverein. As the regression results show, there is again a significant interaction effect between this measure of the strength of the milieu and today's share of Catholics in a municipality. This is the case for both the prewar measure (Table 4, Model 1) and the interwar measure (Table 4, Model 2). As Figure 7 shows, high regional Volksverein membership is associated with a negative effect of Catholicism on AfD share in 2017, whereas low Volksverein membership is associated with a positive effect of Catholicism.
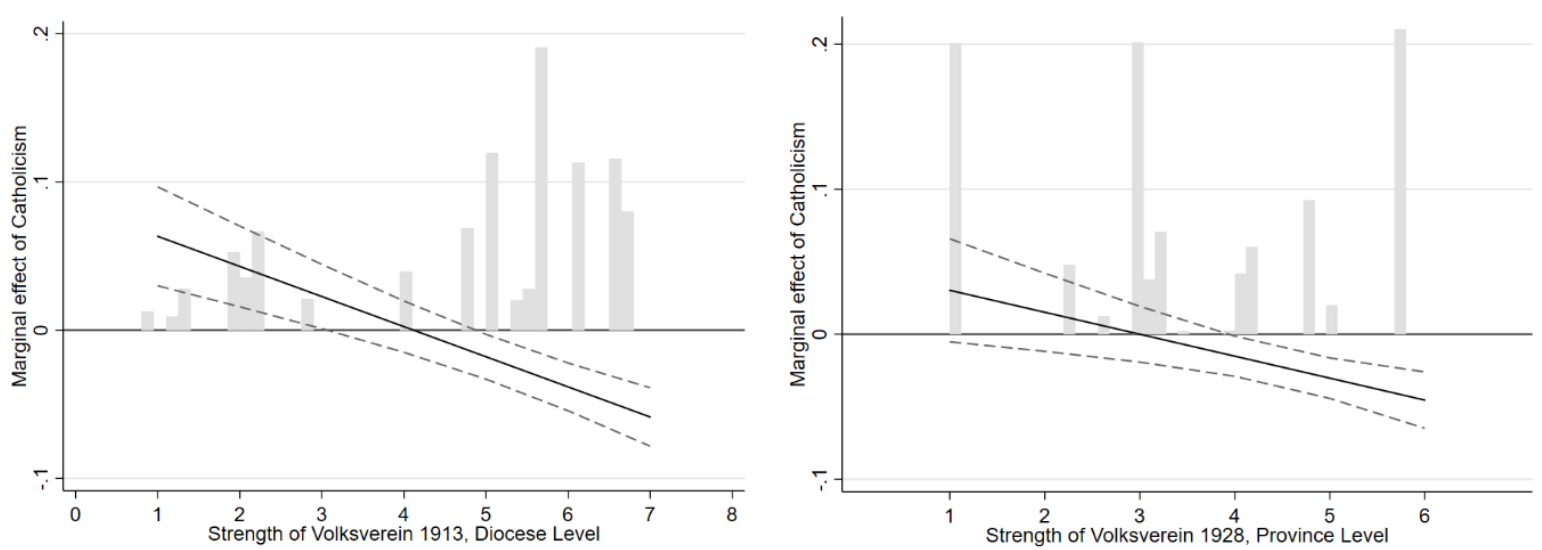

Figure 7: Regional strength of the Volksverein and marginal effect of Catholicism on AfD vote

Obviously, the Volksverein was just one specific type of Catholic association and cannot be taken as a direct measure of the strength of Catholic associations, let alone the Catholic milieu. However, as the discussion above has shown, other indicators of the strength and coherence of the Catholic milieu paint a similar picture. The immediate mobilization of the Catholic milieu was, thus, stronger in regions where oppression was more intense, and these differences are associated with differences in voting behavior today. But has this association persisted? 
To test this, I use my data on Katholikentag participation in the $21^{\text {st }}$ century. Again, we observe the now familiar interaction effect between the measure of the Catholic milieu and Catholic population shares (Table 4, Model 3). In dioceses which are overproportionally represented at the Katholikentag festivals, the Catholic population share is negatively associated with the AfD result in the election of 2017. This is not the case in dioceses that are underrepresented at these festivals (Figure 8).?

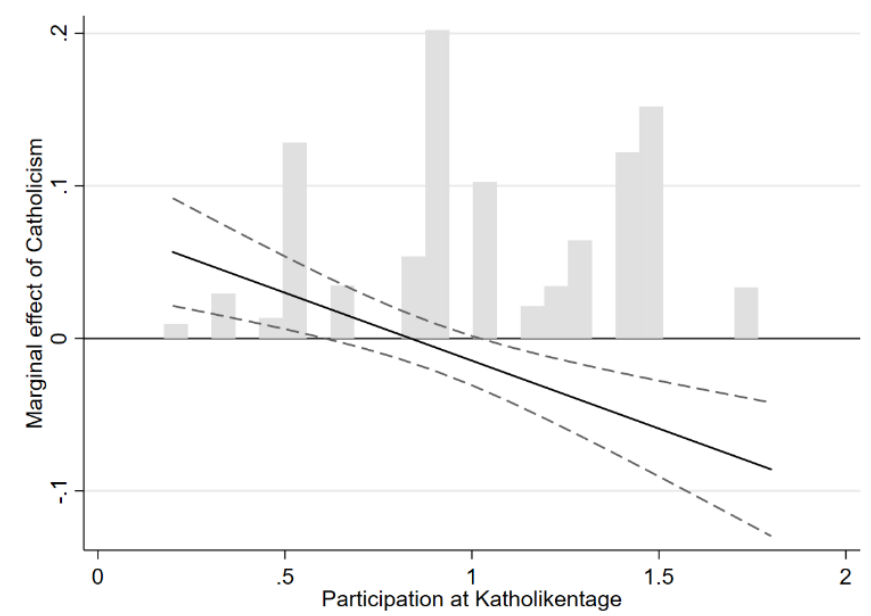

Figure 8: Participation at Katholikentag festivals and marginal effect of Catholicism on AfD share

\begin{tabular}{|c|c|c|c|}
\hline & $\begin{array}{c}(1) \\
\text { Volksverein } \\
1913\end{array}$ & $\begin{array}{c}(2) \\
\text { Volksverein } \\
1928\end{array}$ & $\begin{array}{c}(3) \\
\text { Katholikentag } \\
\text { festivals }\end{array}$ \\
\hline Share Catholics & $\begin{array}{c}0.088^{* * *} \\
(0.021)\end{array}$ & $\begin{array}{l}0.050+ \\
(0.025)\end{array}$ & $\begin{array}{c}0.079 * * \\
(0.023)\end{array}$ \\
\hline Volksverein 1913 & $\begin{array}{l}1.040^{* *} \\
(0.315)\end{array}$ & & \\
\hline Volksverein '13 x Catholic & $\begin{array}{c}-0.021 * * * \\
(0.004)\end{array}$ & & \\
\hline Volksverein 1928 & & $\begin{array}{l}0.521 * \\
(0.203)\end{array}$ & \\
\hline Volksverein '28 x Catholic & & $\begin{array}{c}-0.015^{* *} \\
(0.005)\end{array}$ & \\
\hline Katholikentag participation & & & $\begin{array}{c}2.441 \\
(1.464)\end{array}$ \\
\hline Katholikentage $\mathrm{x}$ Catholic & & & $\begin{array}{c}-0.089 * * \\
(0.025)\end{array}$ \\
\hline Controls & YES & YES & YES \\
\hline $\mathbf{N}$ & 8097 & 8043 & 8097 \\
\hline r2 & 0.551 & 0.530 & 0.548 \\
\hline
\end{tabular}

Table 4: Analysis of mechanism

\footnotetext{
${ }^{9}$ An alternative mechanism discussed in the literature is the role of the clergy. Arguably, this elite-based mechanism should make churchgoing Catholics most resistant to the AfD. As I show in Appendix E, however, regional levels of church attendance are positively correlated with AfD support.
} 


\section{Evidence on the individual level}

So far, I have only analyzed municipal-level election results. While I tried to minimize the risk of an ecological fallacy in several ways, there remains a risk that my results are driven by the behavior of nonCatholics. So, I now move to the individual level using the cumulated pre- and post-election cross-section of the GLES. Individual level data offer a particularly hard test for my hypothesis since the effect of regional historical Catholic mobilization is not necessarily restricted to members of the Catholic Church. Firstly, it may have also affected people who left the Church as adults. Secondly, in regions where Catholicism has a prominent role in society, the effect may spill over to non-Catholics. Only estimating an effect for Church members thus arguably underestimates the effect of the historical mobilization of Catholics.

A second challenge is that the number of AfD voters in standard surveys is still very small. In the GLES dataset, there are only 39 West German Catholics who report to have voted for the AfD. So rather than studying reported AfD voting, I use an 11-point feeling thermometer that asks people about their general view of a party. This measure also fits my theoretical argument, since I argue that Prussian Catholics should display greater resistance toward the AfD. This resistance is most pronounced among those who give the AfD the lowest possible thermometer score (a full $62 \%$ of West Germans, compared to just $2 \%$ for the SPD and 3\% for the CDU respectively). I thus dichotomize the dependent variable into those most resistant and those at least somewhat open to the AfD. Figure 9 reports the share of (non-)Catholics within and outside of former Prussia who report the strongest opposition to the AfD. ${ }^{10}$ As the graph shows, there is no discernible difference between non-Catholics within and outside of former Prussia. Among Catholics, however, such a difference does exist: The share of Prussian Catholics who report the strongest opposition to the AfD is more than 7 percentage points higher than the share of non-Prussian Catholics.

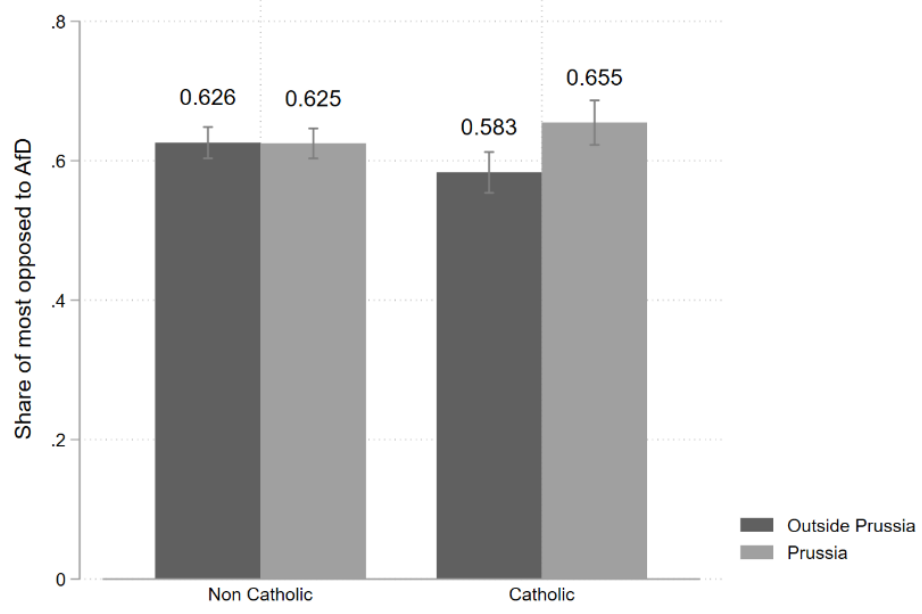

Figure 9: Share of West Germans most opposed to the AfD $83 \%$ Confidence intervals displayed

10 The GLES contains the electoral district in which respondents live. In mixed districts, I assign individuals a "Prussianness score" that is equivalent to the share of the district population living in Prussian municipalities. In Figure 9, I treat individuals as "Prussian" if their district is more than $50 \%$ Prussian. 
In Table 5, I analyze whether this difference remains statistically significant when controlling for a number of alternative explanations. To maintain consistency with the models at the aggregate level, I recode the variable such that a negative coefficient corresponds to a higher likelihood of reporting maximal opposition to the AfD (and thus a lower likelihood of supporting it). The table reports the results of a set of logit models that seek to explain AfD affinity among Catholics. As control variables, I include gender, age, level of education, household income, and employment status. Since respondents are sampled in electoral districts, I cluster standard errors at this level. Moreover, since the survey does not contain any Catholic respondents from either Prussian or non-Prussian districts in several states, I refrain from adding state-level fixed effects.

Both of my two measures of historical oppression in a voter's district are negatively related to support for the AfD, although only the effect of the Prussia measure is statistically significant. To test for the mechanism of historical persistence, I include my three familiar measures: Volksverein membership in 1913 and 1928, and Katholikentag participation. All three measures are significantly associated with lower support for the AfD.

\begin{tabular}{|c|c|c|c|c|c|}
\hline & $\begin{array}{c}\text { (1) } \\
\text { Prussia }\end{array}$ & $\begin{array}{c}\text { (2) } \\
\text { Kulturkampf }\end{array}$ & $\begin{array}{c}(3) \\
\text { Volksverein } \\
1913\end{array}$ & $\begin{array}{c}(4) \\
\text { Volksverein } \\
1928\end{array}$ & $\begin{array}{c}\text { (5) } \\
\text { Katholikentag }\end{array}$ \\
\hline Prussia & $\begin{array}{l}-0.418^{*} \\
(0.169)\end{array}$ & & & & \\
\hline Kulturkampf intensity & & $\begin{array}{l}-0.121 \\
(0.099)\end{array}$ & & & \\
\hline Volksverein 1913 & & & $\begin{array}{c}-0.108^{* *} \\
(0.038)\end{array}$ & & \\
\hline Volksverein 1928 & & & & $\begin{array}{l}-0.111 * \\
(0.045)\end{array}$ & \\
\hline Katholikentag partic & & & & & $\begin{array}{c}-0.634 * * \\
(0.199)\end{array}$ \\
\hline Female & $\begin{array}{c}-0.598^{* * *} \\
(0.170)\end{array}$ & $\begin{array}{c}-0.593^{* * *} \\
(0.170)\end{array}$ & $\begin{array}{c}-0.601 * * * \\
(0.170)\end{array}$ & $\begin{array}{c}-0.609 * * * \\
(0.169)\end{array}$ & $\begin{array}{c}-0.589 \text { *** } \\
(0.167)\end{array}$ \\
\hline Age & $\begin{array}{l}-0.006 \\
(0.005)\end{array}$ & $\begin{array}{l}-0.006 \\
(0.005)\end{array}$ & $\begin{array}{l}-0.005 \\
(0.005)\end{array}$ & $\begin{array}{l}-0.006 \\
(0.005)\end{array}$ & $\begin{array}{l}-0.006 \\
(0.005)\end{array}$ \\
\hline Education high & $\begin{array}{c}-0.644^{* *} \\
(0.197)\end{array}$ & $\begin{array}{c}-0.624^{* *} \\
(0.198)\end{array}$ & $\begin{array}{c}-0.596^{* *} \\
(0.196)\end{array}$ & $\begin{array}{c}-0.622^{* *} \\
(0.194)\end{array}$ & $\begin{array}{c}-0.577^{* *} \\
(0.190)\end{array}$ \\
\hline Unemployed & $\begin{array}{l}-0.111 \\
(0.344)\end{array}$ & $\begin{array}{l}-0.153 \\
(0.345)\end{array}$ & $\begin{array}{l}-0.078 \\
(0.340)\end{array}$ & $\begin{array}{l}-0.120 \\
(0.345)\end{array}$ & $\begin{array}{l}-0.091 \\
(0.339)\end{array}$ \\
\hline Household income & $\begin{array}{l}-0.010 \\
(0.063)\end{array}$ & $\begin{array}{l}-0.012 \\
(0.065)\end{array}$ & $\begin{array}{l}-0.011 \\
(0.064)\end{array}$ & $\begin{array}{l}-0.009 \\
(0.064)\end{array}$ & $\begin{array}{l}-0.003 \\
(0.063)\end{array}$ \\
\hline Constant & $\begin{array}{l}1.119^{*} \\
(0.477)\end{array}$ & $\begin{array}{l}1.126^{*} \\
(0.480) \\
\end{array}$ & $\begin{array}{l}1.355^{* *} \\
(0.486) \\
\end{array}$ & $\begin{array}{l}1.261^{* *} \\
(0.466) \\
\end{array}$ & $\begin{array}{l}1.421 * * \\
(0.475) \\
\end{array}$ \\
\hline $\begin{array}{l}\mathrm{N} \\
\mathrm{r} 2\end{array}$ & $\begin{array}{c}789 \\
0.034\end{array}$ & $\begin{array}{c}789 \\
0.028\end{array}$ & $\begin{array}{c}789 \\
0.035\end{array}$ & $\begin{array}{c}789 \\
0.033\end{array}$ & $\begin{array}{c}789 \\
0.037\end{array}$ \\
\hline
\end{tabular}

Standard errors clustered on electoral district level in parentheses. $+\mathrm{p}<0.10{ }^{*} \mathrm{p}<0.05,{ }^{* *} \mathrm{p}<0.01,{ }^{* * *} \mathrm{p}<0.001$

Table 5: Predicted affinity toward the AfD, GLES 2017 
Taken together, the individual-level data thus lend further support to the findings of the aggregate analysis: Catholics in regions which experienced higher degrees of historical oppression and regions with greater levels of Catholic mobilization seem to be more opposed to the AfD than Catholics elsewhere.

\section{Discussion}

This study empirically demonstrates that regional differences in the development of political Catholicism in the $19^{\text {th }}$ and $20^{\text {th }}$ century still shape the development of the German party system and the regionally differentiated rise of the radical right today. When taking these differences into account, the share of Catholics in a West German region has a strong effect on the AfD vote share. In regions where Catholics were historically oppressed, the AfD vote share in more Catholic municipalities is significantly smaller than in less Catholic municipalities. In regions which did not experience oppression, by contrast, the AfD gets the same (or even a larger) vote share in municipalities with more Catholics.

The study demonstrates this empirical regularity on different levels of aggregation and explains it with the divergent development of political Catholicism. In German states where Catholics were oppressed, in particular in Prussia, they developed a tight, strongly organized milieu in which they separated themselves from the state, but also from the clerical hierarchy. By contrast, political Catholicism in Southern Germany remained more closely related to the Church and was less driven by laity.

This difference arguably started to matter politically when the Church began losing its influence over the voting behavior of the faithful. In the 1920s and 1930s, when the Church still had such a direct influence, Catholics in all parts of Germany refrained from voting fascist. When the role of hierarchy declined, however, civil society mobilization remained as an equifinal mechanism in those parts of Germany where Catholics had originally mobilized in response to political oppression.

My findings have important implications for the literature on the persistence of historical political alignments, as well as for the literature on the rise of the radical right. With regard to the former, the paper emphasizes the role that civil society mobilization can play in the transmission of historical experiences. At the same time, my findings raise the question what happens when these organizations come under pressure. After all, the German Catholic Church sees its membership decline rapidly, and the Catholic milieu has largely disappeared.

With regard to the rise of the radical right, the paper's results demonstrate the importance of a regionally differentiated understanding of the conditions that promote or inhibit this rise. Attempts to identify factors that consistently explain the performance of the radical right across an entire country run the risk of overlooking important but regionally differentiated factors. In this sense, this study is a plea to look not just for master narratives of "modernization losers" or "cultural backlash," but to remain alert to the specific historical and cultural context factors that contribute to the success or failure of the radical right. 
Moreover, the study highlights that a complete understanding of the rise of the radical right also requires studying the factors that may prevent people from voting for these parties. In this view, radical right voting is the outcome of a balancing of factors that make these parties an attractive choice and factors that deter voters from supporting them. A growing strength of right-wing authoritarians may have as much to do with the declining force of the deterring factors as with a growing force of attracting factors. Where deterring forces are still strong, as in some Catholic parts of Germany, even a growing strength of the attracting factors may only have a minor effect on electoral results. 


\section{References}

Acharya, Avidit, Matthew Blackwell, and Maya Sen. 2016. "A Culture of Disenfranchisement: How American Slavery Continues to Affect Voting Behavior." Woking Paper

Anderson, Margaret Lavinia. 1986. "The Kulturkampf and the Course of German History." Central European History 19: 82-115.

Apfeld, Brendan. 2019. "Spatial and Temporal University Database."

Arbeitskreis für kirchliche Zeitgeschichte. 2000. "Konfession Und Cleavages Im 19. Jahrhundert. Ein Erklärungsmodell Zur Regionalen Entstehung Des Katholischen Milieus in Deutschland." Historisches Jabrbuch 120: 358 - 95.

Arzheimer, Kai, and Carl C. Berning. 2019. "How the Alternative for Germany (Afd) and Their Voters Veered to the Radical Right, 2013-2017." Electoral Studies Online First.

Bergmann, Knut, Matthias Diermeier, and Judith Niehues. 2018. "Ein Komplexes Gebilde. Eine SozioÖkonomische Analyse Des Ergebnisses Der Afd Bei Der Bundestagswahl 2017." Zeitschrift für Parlamentsfragen: 243-64.

Bruce, Steve. 2003. Politics and Religion Cambridge: Polity.

Cantoni, Davide, Felix Hagemeister, and Mark Westcott. 2019. "Persistence and Activation of Right-Wing Political Ideology." Working Paper

Charnysh, Volha. 2015. "Historical Legacies of Interethnic Competition: Anti-Semitism and the Eu Referendum in Poland." Comparative Political Studies 48: 1711-45.

Coffé, Hilde, Bruno Heyndels, and Jan Vermeir. 2007. "Fertile Grounds for Extreme Right-Wing Parties: Explaining the Vlaams Blok's Electoral Success." Electoral Studies 26: 142-55.

Colantone, Italo, and Piero Stanig. 2018. "The Trade Origins of Economic Nationalism: Import Competition and Voting Behavior in Western Europe." American Journal of Political Science 62: 93653.

Colella, Fabrizio, Rafael Lalive, Seyhun Orcan Sakalli, and Mathias Thoenig. 2019. "Inference with Arbitrary Clustering." IZA DP No. 12584

Elff, Martin, and Sigrid Rossteutscher. 2011. "Stability or Decline? Class, Religion and the Vote in Germany." German Politics 20: 107-27.

Falter, Jürgen W. 1991. Hitlers Wäbler. München: Beck.

Fitzgerald, Jennifer. 2018. Close to Home. Cambridge: Cambridge University Press.

Gidron, Noam, and Peter A. Hall. 2017. "The Politics of Social Status: Economic and Cultural Roots of the Populist Right." British Journal of Sociology 68: S57-S84.

Harteveld, Eelco, Wouter van der Brug, Sarah De Lange, and Tom van der Meer. 2018. "Multiple Paths to the Populist Radical Right: Voting for Populist Radical Right Parties in Cities and the Countryside." Paper presented at the Paper presented in Harvard University's Populism, Nationalism and Radical Politics Study Group.

Heitzer, Horstwalter. 1979. Der Volksverein Für Das Katholische Deutschland Im Kaiserreich, 1890-1918. Mainz: Matthias-Grünewald-Verlag.

Hoerner, Julian M., Alexander Jaax, and Toni Rodon. 2019. "The Long-Term Impact of the Location of Concentration Camps on Radical-Right Voting in Germany." Research \& Politics 6.

Homola, Jonathan, Miguel M. Pereira, and Margit Tavits. 2020. "Legacies of the Third Reich: Concentration Camps and out-Group Intolerance." American Political Science Review 114: 573-90.

Immerzeel , Tim, Eva Jaspers, and Marcel Lubbers. 2013. "Religion as Catalyst or Restraint of Radical Right Voting?" West European Politics 36: 946-68.

Inglehart, Ronald F., and Pippa Norris. 2016. "Trump, Brexit, and the Rise of Populism: Economic HaveNots and Cultural Backlash." KS Faculty Research Working Paper Series RWP16-026

Jäckle, Sebastian, Uwe Wagschal, and Andreas Kattler. 2018. "Distanz Zur Grenze Als Indikator Für Den Erfolg Der Afd Bei Der Bundestagswahl 2017 in Bayern?" Zeitschrift für Vergleichende Politikwissenschaft 12: 539-66.

Klein, Gotthard. 1996. Der Volksverein Für Das Katholische Deutschland 1890-1933. Geschichte, Bedeutung, Untergang. Paderborn: F. Schöningh.

Lepsius, M. Rainer. 1966. "Parteiensystem Und Sozialstruktur: Zum Problem Der Demokratisierung Der Deutschen Gesellschaft." In Wirtschaft, Geschichte Und Wirtschaftsgeschichte. Festschrift Zum Geburtstag 
Von Friedrich Lütge, eds. Wilhelm Abel, Knut Borchardt, Hermann Kellenbenz and Wolfgang Zorn. Stuttgart: Gustav Fischer. 371-93.

Lönne, Karl-Egon. 1986. Politischer Katholiz̧ismus Im 19. Und 20. Jabrhundert. Frankfurt a.M.: Suhrkamp

Lösche, Peter, and Franz Walter. 2000. "Katholiken, Konservative Und Liberale: Milieus Und Lebenswelten Bürgerlicher Parteien in Deutschland Während Des 20. Jahrhunderts." Geschichte und Gesellschaft 26: 471-92.

McNamara, Kathleen R. 2017. "Constructing Economic Interests: Geography, Culture \& the Liberal International Order." Prepared for "Understanding Challenges to the Contemporary Global Order", Filabach, Switzerland, 6-7 October

Meyer, Nonna. 2013. "From Jean-Marie to Marine Le Pen: Electoral Change on the Far Right." Parliamentary Affairs 66: 160-78.

Minkenberg, Michael. 2018. "Religion and the Radical Right." In The Oxford Handbook of the Radical Right, ed. Jens Rydgren. Oxford: Oxford University Press. 366-93.

Neundorf, Anja, and Grigore Pop-Eleches. 2019. "Dictators and Their Subjects: Authoritarian Attitudinal Effects and Legacies." Comparative Political Studies Online First.

Nipperdey, Thomas. 1961. Die Organisation Der Deutschen Parteien Vor 1918. Düsseldorf: Droste.

Ochsner, Christian, and Felix Roesel. 2019. "Populist Campaigning and Salient History: The Case of the Turkish Sieges of Vienna." Working Paper

Pop-Eleches, Grigore, and Joshua A Tucker. 2017. Communism's Shadow: Historical Legacies and Contemporary Political Attitudes. Princeton: Princeton University Press.

Putnam, Robert. 1993. Making Democracy Work: Civic Traditions in Modern Italy. Princeton: Princeton University Press.

Richter, Christoph, and Lukas Bösch. 2017. "Demokratieferne Räume? Wahlkreisanalyse Zur Bundestagswahl 2017."

Ross, Ronald J. 1998. The Failure of Bismarck's Kulturkampf: Catholicism and State Power in Imperial Germany, 1871 1887. Washington, D.C.: Catholic University of America Press.

Rydgren, Jens. 2009. "Social Isolation? Social Capital and Radical Right-Wing Voting in Western Europe." Journal of Civil Society 5: 129-50.

Siegers, Pascal, and Alexander Jedinger. 2020. "Religious Immunity to Populism: Christian Religiosity and Public Support for the Alternative for Germany." German Politics: 1-21.

Spenkuch, Jörg L., and Philipp Tillmann. 2018. "Elite Influence? Religion and the Electoral Success of the Nazis." American Journal of Political Science 62: 19-36.

Strötz, Jürgen. 2005. Der Katholizismus Im Deutschen Kaiserreich 1871 Bis 1918. Strukturen Eines Problematischen Verbältnisses Zwischen Widerstand Und Integration. Hamburg: Verlag Dr. Kovac.

Voigtländer, Nico, and Hans-Joachim Voth. 2012. "Persecution Perpetuated: The Medieval Origins of AntiSemitic Violence in Nazi Germany." The Quarterly Journal of Economics 127: 1339-92.

Whyte, John H. 1981. Catholics in Western Democracies a Study in Political Behaviour. Dublin: Gill and Macmillan.

Wittenberg, Jason. 2006. Crucibles of Political Loyalty: Church Institutions and Electoral Continuity in Hungary. Cambridge: Cambridge University Press.

Ziemann, Benjamin. 2000. "Der Deutsche Katholizismus Im Späten 19. Und 20. Jahrhundert. Forschungstendenzen Auf Dem Weg Sozialgeschichtlicher Fundierung Und Erweiterung." Archiv für Sozialgeschichte 40: 402-22. 


\section{Appendix}

\section{The long-term effects of oppression: Prussia, Political Catholicism and the Alternative für Deutschland}

\section{Content}

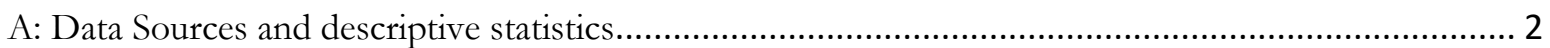

Control variables used in the analyses of West German municipalities ............................................. 2

Table A1: Descriptive statistics on variables used in the main analysis......................................... 2

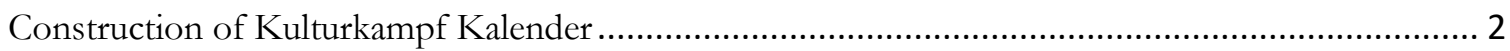

Statistics on the intensity of Catholic mobilization .......................................................................... 3

Table A2: Membership share of the "Volksverein" among all Catholics in 1913 and 1928 ............ 3

B: Alternative standard errors for main analysis ....................................................................... 4

Table B1: Main specification with alternative standard errors ............................................... 4

Table B2: Intensity specification with alternative standard errors .............................................. 5

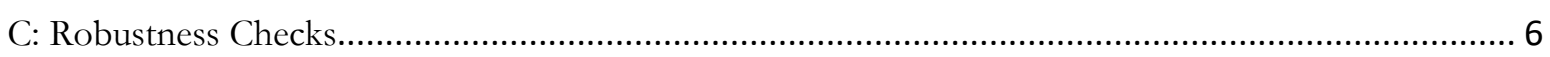

Table C1: Robustness Checks for East Germany and Catholic municipalities ............................. 6

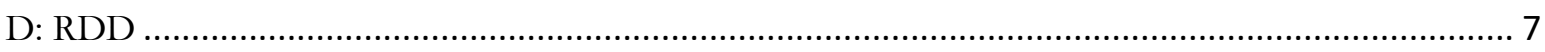

Table D1: Balance of the RDD, averages weighted by population.................................................. 7

Table D2: Full model of the RDD with different cutoffs ........................................................... 8

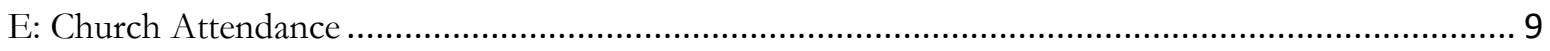

Table E1: Effect of Church Attendance....................................................................................... 9 


\section{A: Data Sources and descriptive statistics}

\section{Control variables used in the analyses of West German municipalities}

In table A1, I summarize the data used in the main analyses for West Germany. The municipal data were collected and generously shared by Philip Manow. I complement them with data on Catholicism from the German census and data on university locations taken from Apfeld (2017).

\begin{tabular}{lccccc}
\hline & nobs & mean & sd & min & max \\
\hline AfD share & 8370 & 11.04 & 4.01 & 0.00 & 33.33 \\
Share Catholics & 8392 & 41.07 & 30.26 & 0.00 & 100.00 \\
Prussia & 8391 & 0.50 & 0.50 & 0.00 & 1.00 \\
Unemployment & 8230 & 1.68 & 0.96 & 0.00 & 9.59 \\
Low-wage employment & 8323 & 10.37 & 2.18 & 0.00 & 67.86 \\
Manufacturing empl & 8275 & 21.97 & 14.72 & 0.00 & 96.87 \\
Regular employment & 8318 & 37.87 & 4.74 & 0.57 & 64.15 \\
Population & 8392 & 7.66 & 36.46 & 0.01 & 1706.70 \\
University & 8392 & 0.01 & 0.07 & 0.00 & 1.00 \\
Share Foreigners & 8368 & 21.73 & 4.98 & 0.00 & 85.91 \\
Population > 65 & 8371 & 19.52 & 4.17 & 0.00 & 68.18 \\
Female Population Share & 8392 & 50.31 & 1.98 & 21.23 & 83.33 \\
Close to border & 8392 & 0.06 & 0.24 & 0.00 & 1.00 \\
\hline
\end{tabular}

Table A1: Descriptive statistics on variables used in the main analysis

\section{Construction of Kulturkampf Kalender}

To construct the index of regional Kulturkampf intensity used in my analyses, I use the "Kulturkampf Kalender" published by the Frankfurter Zeitung in 1875/76. Typical entries of this calendar read:

"15/06/1875 - Bochum - a meeting which sought to discuss the formation of an association for supporting barred priests has been dissolved by the police."

“15/06/1875 - Freiburg - Pastor Gerber was sentenced to five months, copy editor Dilger to two months in prison because of press delicts."

While the first entry refers to a specific municipality in which the event occurred, the second entry only refers to the court district. I have thus decided to code all entries on the district level.

Finally, 27 coded events refer to dioceses, not to districts. Typically, they refer to measures against bishops. An example is:

“07/07/1875 - Minden - the Royal government has instructed the bishop of Paderborn to take residence in the fortress Wesel."

I assign all such entries to all municipalities in the respective diocese.

The resulting regional distribution of the Kulturkampf index is illustrated by Figure 2 in the main paper. 


\section{Statistics on the intensity of Catholic mobilization}

Table A2 shows the share of all Catholics organized in the "Volksverein für das katholische Deutschland" in 1913 (diocesan level) and 1928 (provincial level). The data come from the book on the Volksverein by Heitzer (1979) and Klein (1996).

At both points in time, the Volksverein organized a substantially higher share of Prussian Catholics than of non-Prussian Catholics.

\begin{tabular}{|c|c|c|c|}
\hline \multicolumn{4}{|c|}{ Volksverein } \\
\hline Diocese & $\begin{array}{r}\text { Membership } \\
1913\end{array}$ & Province/State & $\begin{array}{r}\text { Membership } \\
1928\end{array}$ \\
\hline \multicolumn{4}{|c|}{ Prussia } \\
\hline Münster & 6.8 & Westphalia & 5.8 \\
\hline Paderborn & 6.5 & Hanover & 5.8 \\
\hline Cologne & 6.1 & Hessen-Nassau & 4.2 \\
\hline Hildesheim & 5.7 & Hohenzollern & 3.5 \\
\hline Osnabrück & 5.6 & Schleswig-Holstein & 3.1 \\
\hline Fulda & 5.5 & Rhine province & 3.0 \\
\hline Limburg & 5.0 & & \\
\hline Trier & 2.2 & & \\
\hline \multicolumn{4}{|c|}{ Non-Prussia } \\
\hline Speyer & 5.3 & Oldenburg & 5.0 \\
\hline Rottenburg & 5.0 & Württemberg & 4.8 \\
\hline Freiburg & 4.8 & Hesse & 4.1 \\
\hline Mainz & 4.0 & Saar & 4.0 \\
\hline Würzburg & 2.9 & Baden & 3.2 \\
\hline Bamberg & 2.2 & Bavaria West of Rhine & 3.0 \\
\hline Augsburg & 2.1 & Brunswick & 2.6 \\
\hline Munich & 1.9 & Free Hanseatic Cities & 2.3 \\
\hline Regensburg & 1.3 & Lippe/Waldeck & 2.2 \\
\hline Passau & 1.1 & Bavaria East of Rhine & 1.0 \\
\hline Eichstätt & 0.8 & & \\
\hline
\end{tabular}

Table A2: Membership share of the "Volksverein" among all Catholics in 1913 and 1928 


\section{B: Alternative standard errors for main analysis}

In the main specification in the paper, I estimate Conley standard errors with a cutoff of $50 \mathrm{~km}$ using the procedure developed by Colella, Lalive, Sakalli et al. (2019). However, these standard errors may still be too optimistic. In models 2 and 3 of Table B1, I thus set the cutoff to $20 \mathrm{~km}$ and to $100 \mathrm{~km}$ respectively. For simplicity, I report two specifications: the pure interaction between Prussia and Catholicism and the full model. While these changes affect the size of the standard errors, significance levels remain largely identical.

\begin{tabular}{|c|c|c|c|c|}
\hline & $\begin{array}{c}(1) \\
\text { Interaction_20 }\end{array}$ & $\begin{array}{c}(2) \\
\text { Full_Model_20 }\end{array}$ & $\begin{array}{c}(3) \\
\text { Interaction_100 }\end{array}$ & $\begin{array}{c}(4) \\
\text { Full_Model_100 }\end{array}$ \\
\hline Share Catholics & $\begin{array}{l}0.030^{*} \\
(0.012)\end{array}$ & $\begin{array}{c}0.022^{* *} \\
(0.007)\end{array}$ & $\begin{array}{c}0.030 \\
(0.022)\end{array}$ & $\begin{array}{c}0.022 \\
(0.016)\end{array}$ \\
\hline Prussia & $\begin{array}{l}1.399 * * \\
(0.483)\end{array}$ & $\begin{array}{c}1.233^{* * *} \\
(0.314)\end{array}$ & $\begin{array}{l}1.399 * \\
(0.669)\end{array}$ & $\begin{array}{l}1.233^{* *} \\
(0.445)\end{array}$ \\
\hline Prussia x Catholic & $\begin{array}{c}-0.081 * * * \\
(0.014)\end{array}$ & $\begin{array}{c}-0.057 * * * \\
(0.009)\end{array}$ & $\begin{array}{c}-0.081 * * \\
(0.025)\end{array}$ & $\begin{array}{c}-0.057 * * \\
(0.018)\end{array}$ \\
\hline Unemployment & & $\begin{array}{c}1.216^{* * *} \\
(0.123)\end{array}$ & & $\begin{array}{c}1.216^{* * *} \\
(0.180)\end{array}$ \\
\hline Low-wage empl & & $\begin{array}{c}-0.339 * * * \\
(0.068)\end{array}$ & & $\begin{array}{c}-0.339 * * \\
(0.120)\end{array}$ \\
\hline Manufacturing empl & & $\begin{array}{c}0.012^{* *} \\
(0.004)\end{array}$ & & $\begin{array}{l}0.012 * * \\
(0.004)\end{array}$ \\
\hline Regular empl & & $\begin{array}{c}0.183^{* * *} \\
(0.031)\end{array}$ & & $\begin{array}{c}0.183^{* * *} \\
(0.042)\end{array}$ \\
\hline Population & & $\begin{array}{c}-0.002^{* * *} \\
(0.000)\end{array}$ & & $\begin{array}{c}-0.002^{* * *} \\
(0.000)\end{array}$ \\
\hline University & & $\begin{array}{c}-1.750 * * * \\
(0.289)\end{array}$ & & $\begin{array}{c}-1.750 * * * \\
(0.386)\end{array}$ \\
\hline Share Foreigners & & $\begin{array}{c}0.007 \\
(0.028)\end{array}$ & & $\begin{array}{c}0.007 \\
(0.034)\end{array}$ \\
\hline Population $>65$ & & $\begin{array}{c}0.050 \\
(0.033)\end{array}$ & & $\begin{array}{l}0.050+ \\
(0.030)\end{array}$ \\
\hline Female Pop Share & & $\begin{array}{c}-0.427 * * * \\
(0.084)\end{array}$ & & $\begin{array}{c}-0.427 * * * \\
(0.108)\end{array}$ \\
\hline Close to border & & $\begin{array}{c}1.576^{* *} \\
(0.517)\end{array}$ & & $\begin{array}{c}1.576 \\
(0.959)\end{array}$ \\
\hline Constant & $\begin{array}{c}7.348^{* * *} \\
(0.522)\end{array}$ & $\begin{array}{c}21.230^{* * *} \\
(4.169)\end{array}$ & $\begin{array}{c}7.348^{* * *} \\
(0.759)\end{array}$ & $\begin{array}{c}21.230^{* * * *} \\
(6.334)\end{array}$ \\
\hline $\mathbf{N}$ & 8369 & 8100 & 8369 & 8100 \\
\hline r2 & 0.477 & 0.642 & 0.477 & 0.642 \\
\hline
\end{tabular}

All models contain state fixed effects. $+\mathrm{p}<0.10 * \mathrm{p}<0.05,{ }^{* *} \mathrm{p}<0.01, * * * \mathrm{p}<0.001$

Table B1: Main specification with alternative standard errors

In the specification with my detailed measure of the intensity of oppression, the paper reports a specification in which standard errors are clustered at the level at which historical oppression is measured. For comparison, Table B2 reports Conley standard errors with cutoffs of $20 \mathrm{~km}, 50 \mathrm{~km}$, and $100 \mathrm{~km}$. The clustered standard errors are slightly more conservative and the $50 \mathrm{~km}$ errors reported in the other specifications. 


\begin{tabular}{lcccc}
\hline & $\mathbf{( 1 )}$ & $\mathbf{( 2 )}$ & $\mathbf{( 3 )}$ & $\mathbf{( 4 )}$ \\
& Clustered & Cutoff 20 & Cutoff 50 & Cutoff 100 \\
\hline Share Catholics & 0.030 & $0.030^{* *}$ & $0.030^{*}$ & 0.030 \\
& $(0.019)$ & $(0.009)$ & $(0.015)$ & $(0.020)$ \\
Kulturkampf intensity & $0.656^{*}$ & $0.656^{* *}$ & $0.656^{*}$ & $0.656^{*}$ \\
& $(0.313)$ & $(0.210)$ & $(0.270)$ & $(0.331)$ \\
Kulturkampf x Cath & $-0.026^{*}$ & $-0.026^{* * *}$ & $-0.026^{* *}$ & $-0.026^{*}$ \\
& $(0.012)$ & $(0.007)$ & $(0.009)$ & $(0.012)$ \\
Unemployment & $1.235^{* * *}$ & $1.235^{* * *}$ & $1.235^{* * *}$ & $1.235^{* * *}$ \\
& $(0.156)$ & $(0.130)$ & $(0.165)$ & $(0.188)$ \\
Low-wage employment & $-0.324^{* *}$ & $-0.324^{* * *}$ & $-0.324^{* *}$ & $-0.324^{* *}$ \\
& $(0.098)$ & $(0.074)$ & $(0.103)$ & $(0.123)$ \\
Manufacturing empl & $0.010^{* *}$ & $0.010^{* *}$ & $0.010^{*}$ & $0.010^{* *}$ \\
& $(0.004)$ & $(0.004)$ & $(0.004)$ & $(0.004)$ \\
Regular employment & $0.181^{* * *}$ & $0.181^{* * *}$ & $0.181^{* * *}$ & $0.181^{* * *}$ \\
& $(0.034)$ & $(0.031)$ & $(0.038)$ & $(0.039)$ \\
Population & $-0.002^{* * *}$ & $-0.002^{* * *}$ & $-0.002^{* * *}$ & $-0.002^{* * *}$ \\
& $(0.000)$ & $(0.000)$ & $(0.000)$ & $(0.000)$ \\
University & $-1.860^{* * *}$ & $-1.860^{* * *}$ & $-1.860^{* * *}$ & $-1.860^{* * *}$ \\
& $(0.505)$ & $(0.307)$ & $(0.350)$ & $(0.419)$ \\
Share Foreigners & -0.000 & -0.000 & -0.000 & -0.000 \\
& $(0.030)$ & $(0.029)$ & $(0.034)$ & $(0.033)$ \\
Population $>$ 65 & 0.038 & 0.038 & 0.038 & 0.038 \\
& $(0.038)$ & $(0.035)$ & $(0.034)$ & $(0.034)$ \\
Female Pop Share & $-0.426^{* * *}$ & $-0.426^{* * *}$ & $-0.426^{* * *}$ & $-0.426^{* * *}$ \\
& $(0.102)$ & $(0.084)$ & $(0.105)$ & $(0.114)$ \\
Close to border & $1.632+$ & $1.632^{* *}$ & $1.632^{*}$ & $1.632+$ \\
Constant & $(0.963)$ & $(0.516)$ & $(0.793)$ & $(0.948)$ \\
& $22.212^{* * *}$ & $22.212^{* * *}$ & $22.212^{* * *}$ & $22.212^{* * *}$ \\
$\mathbf{N}$ & $(5.376)$ & $(4.237)$ & $(5.917)$ & $(6.738)$ \\
r2 & 8100 & 8100 & 8100 & 8100 \\
\hline Al & 0.638 & 0.638 & 0.638 & 0.638 \\
\hline
\end{tabular}

All models contain state fixed effects. $+\mathrm{p}<0.10 * \mathrm{p}<0.05, * * \mathrm{p}<0.01$, *** $\mathrm{p}<0.001$

Table B2: Intensity specification with alternative standard errors 


\section{C: Robustness Checks}

In the main paper, I analyze all municipalities in West Germany. Here, I replicate the regression for those 2,473 municipalities only in which Catholics are at least two thirds of the population in order to reduce the danger of an ecological fallacy. Indeed, in this regression with very Catholic regions, the estimated effect of Catholicism remains statistically significant and becomes substantively bigger (model 1). Moreover, I study whether the effect of Prussian rule also holds for East Germany. As expected, there is no such effect. In fact, there is a weak negative direct effect of Catholicism in a model for East Germany, but no significant difference between Prussian and non-Prussian Catholics (model 2).

\begin{tabular}{|c|c|c|}
\hline & $\begin{array}{c}\text { (1) } \\
\text { Cath Regions }\end{array}$ & $\begin{array}{c}(2) \\
\text { East }\end{array}$ \\
\hline Share Catholics & $\begin{array}{c}0.147^{* *} \\
(0.049)\end{array}$ & $\begin{array}{c}-0.051+ \\
(0.029)\end{array}$ \\
\hline Prussia & $\begin{array}{c}17.958^{* * *} \\
(4.097)\end{array}$ & $\begin{array}{c}0.320 \\
(0.753)\end{array}$ \\
\hline Prussia x Catholic & $\begin{array}{c}-0.250 * * * \\
(0.056)\end{array}$ & $\begin{array}{l}-0.025 \\
(0.030)\end{array}$ \\
\hline Unemployment & $\begin{array}{c}1.069^{* * *} \\
(0.293)\end{array}$ & $\begin{array}{c}0.599 * * \\
(0.203)\end{array}$ \\
\hline Low-wage employment & $\begin{array}{l}-0.277^{*} \\
(0.114)\end{array}$ & $\begin{array}{c}-0.795^{* *} \\
(0.250)\end{array}$ \\
\hline Manufacturing empl & $\begin{array}{c}0.003 \\
(0.004)\end{array}$ & $\begin{array}{l}-0.004 \\
(0.008)\end{array}$ \\
\hline Regular employment & $\begin{array}{c}0.152^{* * * *} \\
(0.041)\end{array}$ & $\begin{array}{l}0.178^{*} \\
(0.075)\end{array}$ \\
\hline Population & $\begin{array}{l}-0.013 \\
(0.013)\end{array}$ & $\begin{array}{c}-0.011^{* *} \\
(0.004)\end{array}$ \\
\hline University & $\begin{array}{l}-0.169 \\
(0.975)\end{array}$ & $\begin{array}{l}-1.927 \\
(1.215)\end{array}$ \\
\hline Share Foreigners & $\begin{array}{l}0.067 \\
(0.059)\end{array}$ & $\begin{array}{l}0.005 \\
(0.104)\end{array}$ \\
\hline Population > 65 & $\begin{array}{l}-0.115^{*} \\
(0.047)\end{array}$ & $\begin{array}{c}0.281 * * \\
(0.106)\end{array}$ \\
\hline Female Population Share & $\begin{array}{c}0.073 \\
(0.094)\end{array}$ & $\begin{array}{c}-0.920 * * * \\
(0.207)\end{array}$ \\
\hline Close to border & $\begin{array}{l}1.056 \\
(0.921)\end{array}$ & \\
\hline Constant & $\begin{array}{l}-11.967 \\
(8.296)\end{array}$ & $\begin{array}{c}51.859 * * * \\
(9.669)\end{array}$ \\
\hline $\begin{array}{l}\mathbf{N} \\
\text { r2 }\end{array}$ & $\begin{array}{l}2473 \\
0.610\end{array}$ & $\begin{array}{l}2611 \\
0.641\end{array}$ \\
\hline
\end{tabular}

Table C1: Robustness Checks for East Germany and Catholic municipalities 


\section{$\mathrm{D}: \mathrm{RDD}$}

As already explained in the main paper, the RDD along the Pussian-Bavarian border is not a clean RDD, since the municipalities on both sides of the border are not statistically indistinguishable. As table D1 shows, Prussian municipalities are on average more Catholic. If an effect of Prussian rule was to persistently mobilize Catholics, this may in itself be a treatment effect. In any case, the differences between the municipalities are relatively minor, so that this is still the best possible comparison.

\begin{tabular}{lccc}
\hline & $\begin{array}{c}(\mathbf{1}) \\
\text { Bavaria }\end{array}$ & $\begin{array}{c}(\mathbf{2}) \\
\text { Prussia }\end{array}$ & $\begin{array}{c}\mathbf{( 3 )} \\
\text { Difference }\end{array}$ \\
\hline Catholic share & 28.442 & 33.322 & $4.879^{* * *}$ \\
& $(13.062)$ & $(14.418)$ & $(1.467)$ \\
Unemployment & 2.662 & 2.931 & $0.268^{* *}$ \\
& $(0.970)$ & $(1.443)$ & $(0.129)$ \\
Low-wage employment & 9.134 & 9.925 & $0.791^{* * *}$ \\
& $(1.204)$ & $(1.765)$ & $(0.158)$ \\
Manufact employment & 20.257 & 19.427 & -0.829 \\
& $(12.605)$ & $(10.309)$ & $(1.296)$ \\
Regular employment & 37.234 & 37.103 & -0.131 \\
& $(2.813)$ & $(3.077)$ & $(0.315)$ \\
Share Foreigners & 21.448 & 22.947 & $1.499 * * *$ \\
& $(4.050)$ & $(5.340)$ & $(0.499)$ \\
Population > 65 & 20.990 & 20.820 & -0.170 \\
& $(2.684)$ & $(2.708)$ & $(0.290)$ \\
Female Population Share & 50.922 & 51.543 & $0.622^{* * *}$ \\
& $(1.362)$ & $(1.918)$ & $(0.174)$ \\
\hline Observations & 200 & 155 & 355 \\
\hline
\end{tabular}

Table D1: Balance of the RDD, averages weighted by population 
In the main paper, I only report the findings from the RDD graphically. Here, I present the full model from which Figure 6 in main paper is being derived. Since the municipalities are not fully balanced in terms of the control variables, I also include my standard set of control variables in the models.

Model 1 presents the model used in the paper with a cutoff of $25 \mathrm{~km}$. Models 2 and 3 present slightly smaller and bigger cutoffs. As models 2 shows, the results become insignificant when the cutoff gets too small, also because the balance between the municipalities becomes worse.

\begin{tabular}{|c|c|c|c|}
\hline & $\begin{array}{c}(1) \\
\text { Cutoff } 25 \mathrm{~km}\end{array}$ & $\begin{array}{c}(2) \\
\text { Cutoff } 20 \mathrm{~km} \\
\end{array}$ & $\begin{array}{c}(3) \\
\text { Cutoff } 30 \mathrm{~km}\end{array}$ \\
\hline Prussia & $\begin{array}{c}1.176 \\
(1.720)\end{array}$ & $\begin{array}{c}0.049 \\
(1.961)\end{array}$ & $\begin{array}{c}1.366 \\
(1.495)\end{array}$ \\
\hline Share Catholics & $\begin{array}{c}0.026 \\
(0.024)\end{array}$ & $\begin{array}{l}-0.006 \\
(0.024)\end{array}$ & $\begin{array}{c}0.033 \\
(0.026)\end{array}$ \\
\hline Distance to border & $\begin{array}{c}0.026 \\
(0.058)\end{array}$ & $\begin{array}{c}0.095 \\
(0.117)\end{array}$ & $\begin{array}{l}-0.010 \\
(0.045)\end{array}$ \\
\hline Prussia x Catholic & $\begin{array}{l}-0.128^{*} \\
(0.047)\end{array}$ & $\begin{array}{l}-0.080 \\
(0.052)\end{array}$ & $\begin{array}{c}-0.130^{* *} \\
(0.042)\end{array}$ \\
\hline Prussia x Border & $\begin{array}{l}-0.150 \\
(0.147)\end{array}$ & $\begin{array}{l}-0.107 \\
(0.223)\end{array}$ & $\begin{array}{l}-0.114 \\
(0.102)\end{array}$ \\
\hline Border x Catholic & $\begin{array}{l}-0.001 \\
(0.001)\end{array}$ & $\begin{array}{l}-0.004 \\
(0.004)\end{array}$ & $\begin{array}{c}0.000 \\
(0.001)\end{array}$ \\
\hline Prussia x Catholic x Border & $\begin{array}{c}0.005 \\
(0.003)\end{array}$ & $\begin{array}{c}0.006 \\
(0.006)\end{array}$ & $\begin{array}{c}0.004 \\
(0.003)\end{array}$ \\
\hline Unemployment & $\begin{array}{l}0.530^{*} \\
(0.220)\end{array}$ & $\begin{array}{l}0.438+ \\
(0.241)\end{array}$ & $\begin{array}{c}0.620^{* *} \\
(0.207)\end{array}$ \\
\hline Low-wage employment & $\begin{array}{l}-0.028 \\
(0.098)\end{array}$ & $\begin{array}{l}-0.090 \\
(0.115)\end{array}$ & $\begin{array}{c}0.001 \\
(0.086)\end{array}$ \\
\hline Regular employment & $\begin{array}{l}-0.060 \\
(0.076)\end{array}$ & $\begin{array}{l}-0.015 \\
(0.088)\end{array}$ & $\begin{array}{l}-0.050 \\
(0.067)\end{array}$ \\
\hline Population & $\begin{array}{l}-0.035^{*} \\
(0.015)\end{array}$ & $\begin{array}{l}-0.023 \\
(0.017)\end{array}$ & $\begin{array}{c}-0.038^{* *} \\
(0.013)\end{array}$ \\
\hline University & & & $\begin{array}{c}0.180 \\
(0.916)\end{array}$ \\
\hline Share Foreigners & $\begin{array}{c}0.041 \\
(0.059)\end{array}$ & $\begin{array}{c}0.030 \\
(0.068)\end{array}$ & $\begin{array}{c}0.038 \\
(0.050)\end{array}$ \\
\hline Population > 65 & $\begin{array}{c}-0.108+ \\
(0.063)\end{array}$ & $\begin{array}{l}-0.081 \\
(0.067)\end{array}$ & $\begin{array}{c}-0.105+ \\
(0.060)\end{array}$ \\
\hline Female Population Share & $\begin{array}{l}-0.022 \\
(0.124)\end{array}$ & $\begin{array}{l}-0.121 \\
(0.112)\end{array}$ & $\begin{array}{l}-0.051 \\
(0.113)\end{array}$ \\
\hline Constant & $\begin{array}{l}18.035^{*} \\
(6.836)\end{array}$ & $\begin{array}{c}22.258^{* *} \\
(7.373) \\
\end{array}$ & $\begin{array}{c}18.344^{* *} \\
(6.406)\end{array}$ \\
\hline $\begin{array}{l}\mathrm{N} \\
\mathrm{r} 2\end{array}$ & $\begin{array}{c}350 \\
0.290\end{array}$ & $\begin{array}{c}299 \\
0.270\end{array}$ & $\begin{array}{c}426 \\
0.288\end{array}$ \\
\hline
\end{tabular}

$+\mathrm{p}<0.10, * \mathrm{p}<0.05, * * \mathrm{p}<0.01$

Table D2: Full model of the RDD with different cutoffs 


\section{E: Church Attendance}

As discussed in the theory section of the paper, an alternative mechanism for explaining a negative relationship between Catholicism and radical right voting that is prominently discussed in the literature is the role of the clergy. Arguably, this elite-based mechanism should make practicing Catholics who actually go to church most resistant to the AfD. I test for this possibility (in an admittedly coarse way), using official data on average church attendance by diocese provided by the German Bishops' Conference. As the analysis shows, there is no evidence that Catholics in dioceses with higher Church attendance are more reluctant to support the AfD. To the contrary, church attendance and AfD support are significantly positively associated.

(1)

Church

Attendance

\begin{tabular}{lc}
\hline Share Catholics & $-0.153^{* * *}$ \\
& $(0.014)$ \\
Church Attendance & $-0.408^{* *}$ \\
& $(0.118)$ \\
Attendance x Catholic & $0.015^{* * *}$ \\
& $(0.001)$ \\
Controls & YES \\
& \\
\hline $\mathbf{N}$ & 8097 \\
$\mathbf{r} 2$ & 0.549 \\
\hline
\end{tabular}

$+\mathrm{p}<0.10, * \mathrm{p}<0.05, * * \mathrm{p}<0.01$

Table E1: Effect of Church Attendance 